\title{
Comparing Some Ideas of Ibn Haldun and John Locke about the Epistemology from Some Aspects
}

\author{
Hacer ÂŞIK EV*
}

\begin{abstract}
In this article some opinions of Ibn Haldun who lived at the end of the Middle Age and some opinions of John Locke who lived in the New Age about epistemology were tried to be compared from some aspects. For both thinkers, who have rejected the innatism and accepted the mind as a blank slate at first, the source of knowledge is senses and thought. According to Ibn Haldun, the knowledge's subject is universals, and according to Locke, the knowledge's subject is ideas and the relations between ideas. Ibn Haldun asserted that the perceptions about concretes are more reliable and far from fault than abstracts. Locke accepted that the intuitive knowledge is the most evident and reliable knowledge.
\end{abstract}

Keywords: Ibn Haldun, John Locke, epistemology, knowledge

\section{SUMMARY}

This study aims to compare some ideas of Ibn Haldun (1332-1406) about epistemology, who lived at the end of the Middle Age, and some ideas of John Locke (1632-1704), who lived in the New Age. Ibn Haldun is generally accepted as a founder of the philosophy of history and one of the pioneers of the sociology. J. Locke, who has contributed to the $18^{\text {th }}$ century

*Researcher, E-mail:hacerev@hotmail.com 
Enlightment Age, is generally accepted as a prime mover of empiricism and liberal ideology.

Both Ibn Haldun and Locke give full weight to reason and freedom. Ibn Haldun asserts that reason is a power that differs human being from animals and that dominates human beings to animals. Locke asserts that individuals should be free both in their thoughts and actions and that they should put their actions into order in accordance with mind.

Both thinkers reject the inniatism and accept mind at first as a blank slate and for both of them the sources of knowledge are senses and thought. According to Ibn Haldun, human beings are born with some features necessary to obtain the knowledge later though they don't have them when they are born and these features begin to reach the necessary maturity to obtain the knowledge as from the discretion age. According to Ibn Haldun's epistemology, with their nature human beings are ignorant but as from the discretion age they give up the imitative learning and begin to learn consciously and actively and in this way they begin to realize themselves. Locke, who doesn't accept the existence of innate concepts, principles and ideas, explains why they are asserted as native when human beings find generally proposals with no suspicion about their being native.

According to both Ibn Haldun and J. Locke, since it is impossible to produce knowledge without any raw materials to process in mind, they are the senses that supply the perception flow of the external objects. So, senses are the first of the knowledge sources and the second is the thought that make operations on data which are perceived and carried to mind by senses.

According to Ibn Haldun, the subject of knowledge isn't any abstractions but universals which have the equivalents in presences and realworld; in other words they are primary universals. According to Locke the subject of knowledge is ideas and relations between ideas.

On the topic of knowledge fields, Ibn Haldun asserts that he has observed three knowledge fields in human being's self. The first is the physical field of which knowledge is reached with senses. The second is the self field and the mental field over the sense field and the third is the souls and angels field which human beings feel within them and they gain from works. In Locke's epistemology, knowledge fields are classified as actual and habitual knowledge and according to indecency degrees they are classified as perceptual, evidential and sensorial knowledge.

Ibn Haldun asserts that on the value of knowledge perceptions on concrete presences are more reliable and far away from mistakes. In fact, Ibn 
Haldun accepts that the knowledge on the spiritual field is directly reachable and more reliable, but it is limited. Locke accepts that perceptual knowledge with no mediator idea is the clearest and the most reliable knowledge. In Locke's epistemology from the view point of reliability the second is the evidential knowledge and the third is the sensorial knowledge.

As it is seen, although there is a three-century- difference between the terms they lived and although they lived in different cultural environments, there are many similarities between Ibn Haldun's and J. Locke's ideas about epistemology. 


\title{
İbn Haldun ile John Locke'un Epistemoloji ile ilgili Bazı Görüşlerinin Karşılaştırılması
}

\author{
Dr. Hacer ÂŞIK EV"
}

\begin{abstract}
ÖZ. Bu makalede Ortaçağ'ın sonlarında yaşayan İbn Haldun ile Yeniçağ'da yaşayan John Locke'un bilgi anlayışları bazı yönlerden karşılaştırılmaya çalış1ldı. Doğuştan getirilen fikirler görüşüne karşı çıkarak başlangıçta zihni bütün özniteliklerinden yoksun boş bir levha veya beyaz bir kâğıt olarak düşünen her iki düşünür için bilginin kaynağı dış duyular ile düşünüm veya akıldır. İbn Haldun'a göre bilginin konusu varlıkta karşılığı ve gerçek içeriği olan tümeller Locke'a göre ise ideler ve ideler arasındaki bağıntılardır. İbn Haldun somut varlıklarla ilgili algıların daha güvenilir ve hatadan uzak olduğunu ileri sürerken Locke ise herhangi bir aracı idenin bulunmadığı sezgisel bilgiyi en açık ve en güvenilir bilgi olarak kabul eder.
\end{abstract}

Anahtar Sözcükler: İbn Haldun, John Locke, epistemoloji, bilgi

\section{GİRIŞ}

$\mathrm{Bu}$ araştırma Ortaçağ' ın sonlarında, XIV. yüzyılın ikinci yarısı ve XV. yüzyılın başında yaşayan İbn Haldun (1332-1406) ile Yeniçağ' da yaşayan John Locke'un (1632-1704) epistemoloji ile ilgili bazı görüşlerini karşılaştırmayı amaçlamaktadır. Yaşadığı dönem daha erken olması nedeniyle önce İbn Haldun daha sonra da John Locke'un epistemoloji ile ilgili bazı görüşleri ele alınıp karşılaştırılmaya çalışılacaktır. İbn Haldun

*Araştırmac1, E-posta:hacerev@hotmail.com 
sosyolojinin öncülerinden ve tarih felsefesinin kurucusu, 18. yüzy1l aydınlanmasını etkileyen düşünürlerden biri olan John Locke ise (16321704), epistemoloji konusundaki görüşlerinin yanı sıra duyumculuğun (sansüalizm) ve deneyciliğin (görgücülük, empirizm) Yeniçağ'daki en önemli temsilcisi kabul edilir.

Skolâstik düşünce ve geleneksel eğitim sisteminin egemen olduğu Ortaçağ'ın sonları ile Avrupa'da Rönesans'ın başlarında yaşayan İbn Haldun, kökleri İşbîliye'ye (Sevilla) dayanan, Yemen'in Hadramût bölgesinden olup, XII. yüzyılın sonlarında Endülüs'ün fethi sırasında buraya gelen ve daha sonra da Kuzey Afrika'ya göç edip yerleşen aristokrat ve akademik kökleri olan bir aileden gelir (İbn Haldun, türkçesi Akyüz, 2004).

$\mathrm{O}$, sürekli el değiştiren iktidarların yer aldığ çalkantılı siyasi bir dönemde, aktif olarak siyasi çalışmaların ve gelişmelerin içinde, zaman zaman istemeyerek de olsa, görev almış ve devamlı uyanık olmayı gerektiren tehlikeli bir yaşam sürmüş̧ür. Onun yaşadığı dönem toplumsal, siyasî, ekonomik ve kültürel açıdan bir geçiş dönemidir. Dinamik olduğu kadar son derece karışık da olan bir toplumsal, ekonomik ve siyasi yapı içinde birçok hanedanlığın doğuş, gelişme ve çöküşlerini bizzat yaşayarak gözlemleyen İbn Haldun bu deneyim ve bilgi birikimine dayanarak sosyoloji ilmini kurduğunu şu sözleriyle bildirir: "Bil ki bu inceleyeceğimiz kurallar benim tarafımdan icad edilmiş yeni bir ilim olup faydası çok ve kalpleri şiddetle kendine çeken bir ilimdir." (İbn Haldun, 1989: C. I, 91)

Bazı araştırmacılar yeni bir ilim kuracak kadar özgün fikirlere sahip olan İbn Haldun'un yaşadığ XIX. yüzyıla kadar da ilgi konusu olmadığını ileri sürerler (Al- Azmeh, 1998). Bunlardan Adıvar'a göre, ilk olarak XV. Yüzyılda Osmanlı Türklerinden Muhammed b. Ahmed Hâfiz ed-Din Acamî "İlim Şehri" adlı eserinde ondan bahseder (Adıvar, 1950: 740). Yukarıdaki iddiaların tersine olarak M. A. Enan da 1697 yılında Fransız oryantalist D' Herbelot'un İbn Haldun'un biyografisini kaleme aldığını ve bu çalışma ile batının ilk defa İbn Haldun ile karşılaştığını, fakat bunun kısa ve hatalı olduğunu bildirir (Enan, 1979). Ancak söz konusu çalışma üzerinden yüzyıldan fazla bir zaman geçtikten sonra 1806 yılında Fransız oryantalist Silvestre de Sacy "Chrestomante Arabe""sinda İbn Haldun'un biyografisi ile beraber Mukaddime'den çevirdiği bir bölümü yayınlar ve bu çalışmasından birkaç yıl sonra da Mukaddime'den bir başka bölümü çevirir (Enan, 1979). Bu çalışmalar ile batılıların dikkatini çekmeye başlayan İbn Haldun daha sonraki yıllarda gerek doğuda gerekse batıda sosyoloji, tarih, felsefe, siyaset, ekonomi ve çok az da olsa eğitim ile ilgili bir dizi araştırmaya konu olur. 
Yapılan bu araştırmalar İbn Haldun'un tarih felsefesinin kurucusu, sosyoloji ve daha birçok alanda da öncü fikirlere sahip olduğunu ortaya koymuştur. Örneğin o, John Dewey'den yüzyıllar önce ihtiyaçların karşılanması ve güvenliğin sağlanabilmesi için toplumsal organizasyon ile yardımlaşmanın gerekliliği ve önemi konusuna vurgu yapmış (Gutek, 2001), Marx'tan önce emeğin rolüne işaret ederek art1-değer kavramına yaklaşmıştır. Ayrıca Avrupalı tarihçi ve sosyologlardan uzun yıllar önce de tarihin yalnızca olayların aktarılmasından ibaret olmadı̆̆ını ve altta yatan nedenlere, ekonomik koşullara bakmak gerektiğini ileri sürmüştür. Machiavelli'den 100, Montesquieu'den 350 y1l önce kapsamlı bir siyaset ve devlet teorisi geliştirmiştir (Helvacioğlu, 1999).

İbn Haldun'un eğitim ile ilgili öncü görüşlerini ise şöyle sıralamak mümkündür: $\mathrm{O}$, eğitim-öğretim etkinliklerinde öğrencinin zihinsel gelişiminin ve bireysel farklılıklarının dikkate alınması gerektiği, bunların ihmal edildiği durumlarda ise öğrencide bıkkınlık ve öğrenmeye karşı isteksizlik doğabileceğini ileri sürerek Rousseau (1712-1778) ve $J$. Dewey'ye (1859 -1952) öncülük etmiştir. Yine onun XX. Yüzyllda reformcu eğitim hareketleri sonucunda ortaya çıkan ve fiziksel etkinliği (iş) entelektüel faaliyetin bir tamamlayıcısı ve denge unsuru olarak eğitime sokan "İş Okulu" akımının başta gelen temsilcilerinden olan Dewey'in yanısıra Pestalozzi ve Kerschensteiner'e de öncülük ettiği bir başka konu, yaparak yaşayarak öğrenmenin daha değerli olduğuna vurgu yapmasıdır. İbn Haldun ayrıca herhangi bir alandaki becerinin yaparak yaşayarak öğrenilmesinin öneminin yanısıra bilgi, ahlâk ve başkalarından öğrenilecek meslek, mezhep ve faziletlerin de bizzat o işi yapmak ve o işte uzman olan kişiyi izlemek ile daha kuvvetli ve daha kalıcı bir şekilde öğrenileceğini ileri sürer. Ona göre bir şeyin yalnızca bilgisine sahip olan onu görerek ve uygulayarak öğrenen kimseden geridir. İbn Haldun uzun y1llar önce yaparak yaşayarak öğrenmenin yanında model alarak öğrenmenin önemine de değinmiştir (Ev, 2007).

İbn Haldun'un modern eğitimden yüzyıllar önce üzerinde durduğu diğer konular ise disiplin, eğitimde anlatma yönteminin sakıncaları ve tartışma yönteminin yararları ile ilgilidir. Ona göre, "Öğrenciye sert davranmak iyi bir usul değildir (İbn Haldun, 1977: 40-41), şiddet kötü melekeden olduğundan öğrenciye sert davranılması onlara zarar verir. Bask1 altında tutulan bireyin ruhî yeteneklerinin gelişmesi ve genişlemesi engellenirken girişim ve hamle gücü, hevesi yok olur, böylece birey tembelliğe sürüklenir. Sonuçta sayılan bu olumsuz özellikleri huy haline getiren tembelleşen nefs faziletleri ve iyi huyları kazanma halinden uzaklaşarak yeteneklerini en üst noktasına kadar gerçekleştiremez ve geriler (İbn Haldun, t. y: 989-990).” 
İbn Haldun anlatma yöntemini eğitim-öğretimde etkili bir telkin arac1 olarak görmek, bu yöntem ile sağlam ve köklü melekelerin kazanıldığını ve bu yolla büyüklerden ve hocalardan herhangi bir şey öğrenildiğinde, öğrenilenleri araştırma ve bunların arasından sözü edilen anlamı yakalamak için uzun zahmetlere katlanılmaya ihtiyaç duyulmadığını ileri sürmekle beraber bu yöntemin sakıncalarına da değinir. Ona göre bu yöntemin sakıncaları çok vakit alma, ezberciliğe yol açma ve konuşma melekesinin gelişimini engellemesidir. Eğitim-öğretimde tartışma ise son derece etkin ve yararlı bir yöntemdir. Çünkü bilimsel tartışmalar yapmak bir konu veya davranış1 iyice öğrenmenin (meleke elde edilmesinin), konuşma yeteneğini geliştirmenin ve ilmi konuları zihne yaklaştırıp daha anlaşılabilir bir hale getirmenin en kolay yoludur. Eğer bu ihmal edilirse birey ömrünü ilimle geçirmiş olsa bile herhangi bir konuda rahatça konuşamaz (daha fazla bilgi için bkz. Ev, 2007).

Eğitim ile ilgili görüşlerine "Eğitim Üzerine Düşünceler" adlı eserinde yer veren John Locke ise eğitimin bir ülkeye yararı olacak en önemli işlerden olduğunu ve bir toplumun refahı ve gelişmesinin eğitime bağlı olduğunu düşünür. Küçük yaşlardan itibaren çocukların iyi bir eğitim almaları gerektiğini ve bunun da ailenin çocuğuna karşı temel görevi olduğunu ileri sürer. Aksi halde "tıpkı bir binanın temelinde yapılan hataların sonrasında, örneğin ikinci ve üçüncü katları yaparken düzeltilememesi gibi, eğitimde yapılan hatalar da yaşam boyu bir daha düzeltilemeyecek bozulmalara yol açar" (Locke, 2004: 12). Locke'a göre, eğitimin ana konusu hangi alışkanlıkların geliştirileceğini belirlemektir, bu nedenle çocuğun bedenine ve ruhuna zarar verecek davranışlar alışkanlık haline getirilmemelidir. Çocuğun ruhu su gibi kolay şekillendiğinden, onun sonraki yaşamını etkileyecek olan tohumlar erken ekilmelidir. Bunun da en etkili yolu anne babaların çocuklarına iyi birer örnek olmalarıdır. Çocuklar aslında kötülükleri ve yanlış şeyleri büyüklerinden öğrenirler (daha fazla bilgi için bkz. Locke, 2004).

Locke'a göre çocukların doğru bir kişilik geliştirebilmeleri için eğitimlerinde disiplin gereklidir, çünkü onların yargıya varma güçlerindeki eksiklik katı ve disiplinli bir eğitimi gerekli kılar. Ancak çocuklar kendi hayatlarını sürdürmeleri için gerekli olan yeteneklere sahip oldukça onlara karş1 sertlik göstermek ve onları idare etmeye çalışmak kötü bir davranış olur (Locke, 2004: 147). Çocuklar büyüdükçe özgürlüklerini arttırarak kendilerini korumayı öğrenmelerini sağlamak gerekir. Çünkü doğru ilkelerle ve kökleşmiş alışkanlıklar ile kendini koruyabilen ve kendi başına karar verebilen bir kişiliğe sahip olmanın önkoşulu özgürlüktür. Özgürlüğün yanısıra özgüvenlerinin de gelişmesi için oyun gereklidir. Çocukların hayat 
sevgisiyle dolu, neşeli olmalarının sağlanması; güç ve sağlıklarının pekiştirilmesi onlara doğa tarafından bilgece verilen oynama isteğinin dizginlenmesi ya da sınırlanması yerine teşvik edilmesi ile olur. Hatta eğitimi de oyun gibi algılamaları sağlanırsa özgürce hareket edebilmelerinin verdiği doyumla öğrenme istekleri artar ve gelişmeleri hızlanır (daha fazla bilgi için bkz. Locke, 2004).

Hem İbn Haldun hem de J. Locke özgürlüğün yanısıra akla da büyük önem verirler ve aklın insanı hayvanlardan ayıran ve üstün k1lan bir yeti olduğunu kabul ederler (Locke, 1996: 387; İbn Haldun, t. y: 42). İbn Haldun için dünyayı anlama ve açıklama sürecinde devamlı akla, deneye ve tecrübeye dayanılmalıdır. Onun dinî politik geleneğe ve dinî bilimlere, hatta psikolojik veya doğaüstü faktörlerin içerildiği alana yaklaşımı bile döneminde sergilenenden farklı ve rasyoneldir. (Rosenthal, 1987: 566). Locke için de birey gerek düşüncesinde gerekse eylemlerinde özgür olmalı ve eylemlerini akla göre düzenlemelidir.

Her iki düşünür de doğuştan getirilen fikirler görüşüne karşı çıkarak başlangıçta zihni boş bir levha gibi kabul ederler. Yine her iki düşünür için de bilginin kaynağı duyular ve düşünümdür. Duyular aracıllı̆̆ ile elde edilen duyu verileri zihinsel süreçlerden geçerek bilgiyi oluşturur. İbn Haldun ve J. Locke bilginin konusunun ne olması gerektiği ile ilgili olarak da benzer görüşler ileri sürerler. Duyu bilgileriyle düşünce ürünleri olan genel kavram veya tümelleri birbirinden ayıran İbn Haldun'a göre bilginin konusu dış dünyadaki nesneler, varlıkta karşılığı ve gerçek içeriği olan birinci elden soyutlamalar olan tümellerdir (genel kavramlar). Bilginin konusunu oluşturan bu tümeller her türlü soyutlamalar değildir, bunların dış dünyadaki varlıklara uygunluğu daha fazladır. Bilgiye kaynaklık eden bu genel kavramların oluşturulmasında etkin olan güç hayal gücü yetisidir, bunlar doğrudan dış dünyadaki varlıkların hayal gücü yetisi tarafından soyutlanması ile elde edilir. J. Locke'a göre de bilginin konusu duyum ile eş anlamda kullandığı idedir. Fakat her iki düşünür için de bilginin konusu dış dünyada gerçekliği olan genel kavramlar olmakla beraber yine her ikisi de duyular ile algilanamayan şeyleri yok kabul etmezler.

Görüldüğü gibi biri Ortaçağın sonları biri de Yeniçağda yaşayan iki düşünürün görüşleri arasında bazı benzerlikler bulunmaktadır. Ayrıca bu iki düşünürün epistemolojisinde eğitime felsefî temel oluşturabilecek önemli kavram ve konuların olduğu da görülür. Farklı çağlarda ve farklı kültür çevrelerinde yaşayan felsefe tarihinin bu iki önemli düşünürünün görüşleri arasındaki benzerlikler ve eğitim felsefesine temel oluşturabilecek olan epistemolojilerindeki bazı konular bir araştırmaya konu olacak kadar anlamlı bulunduğundan böyle bir çalışmanın önemli olabileceği düşünülmüştür. 
Aslında bilgiyi konu alan epistemoloji ile nesnesi insan olan eğitim çok da birbirlerine yabancı ve birbirleri ile ilişkisiz olan alanlar değildir. Bir eğitim sisteminin kurulması eğitim teorileriyle, eğitim teorilerinin geliştirilmesi ise eğitim felsefesi ile mümkündür. Dolayısıyla eğitim felsefesi eğitim sisteminin en temel şartıdır. Bir epistemolojiye dayanmayan eğitim felsefesi ise bilgi açısından temelsiz ve çatısı kurulmamış olacağından epistemolojiye dayanmadan ne bir eğitim felsefesi ne de bir eğitim sistemi kurulabilir (Açıkgenç, 2009). Epistemolojinin konusu olan bilginin kaynağı, alanları, konusu ve değeri gibi konular eğitimde öğrenciye aktarılacak olan veya kazandırılması hedeflenen içerik ile de yakından ilgilidir. Örgün veya yaygın eğitimde alıcı durumundakilere ne tür bilgilerin verilmesi gerekir? İçerik olarak aktarılan bilgiler alıcı durumundakilerin bilişsel, duyuşsal, psikomotor ve kültürel gelişim düzeylerine uygun mudur? Eğitim-öğretim programlarında yer alan bilgiler öğrencilerin potansiyel güçlerini geliştirebilecek midir? İşte bu ve benzeri sorular eğitilmiş büreyi üretebilmek için kullanılacak olan içeriğin veya bilginin doğruluk, gerçeğe uygunluk, değeri vb. açısından sorgulanması gereğini ortaya koyar. Bu da epistemoloji ile mümkündür.

Ayrıca bir eğitim sisteminin günün problemlerini tanıyıp onlara çözüm üreterek başarılı ve verimli bir şekilde işlevini gerçekleştirip gelecek için de lokomotif görevini yerine getirebilmesi için tarihi dayanaklarının ortaya çıkartılması gerekir. Geçmiş, bugün ve gelecek boyutlarına sahip olan kapsamlı bir eğitim sisteminin gelişmesi ve kendisinden bekleneni verebilmesi tarihî birikimin iyi bilinmesi, değerlendirilmesi ve ondan gereğince yararlanılması ile mümkündür (Akyüz, 2004). Felsefe tarihinin iki önemli düşünürünün epistemoloji ile ilgili bazı görüşlerinin araştırılıp karşılaştırılmaya çalışıldığı bu araştırmanın eğitim felsefesine düşünsel tarihî bir temel oluşturma açısından katkı sağlayabileceği umulur.

$\mathrm{Bu}$ iki düşünürün eğitim felsefesine de düşünsel açıdan temel oluşturabilecek olan epistemoloji ile ilgili bazı görüşlerinin karşılaştırılması alt başlıklarda ele alınmaya çalışılmıştır.

\section{YÖNTEM}

$\mathrm{Bu}$ çalışma Ortaçağın sonlarında, XIV. yüzyılın ikinci yarısı ve XV. yüzyılın başında yaşayan İbn Haldun (1332-1406) ile Yeni Çağda yaşayan J. Locke'un (1632-1704) epistemoloji ile ilgili bazı görüşlerini karşılaştırmayı amaçlamaktadır. İbn Haldun'un en önemli eseri olan Mukaddime'nin bazı bölümlerinde epistemoloji ile ilgili birtakım bilgiler görülmekle beraber aslında İbn Haldun özel olarak bu konu ile ilgilenmiş değildir. John Locke ise epistemoloji ile özel olarak ilgilenmiş ve bir dost toplantısında din ve 
ahlak ilkeleri üzerine tartışılırken ortak bir karara varılamadığını görünce, insan zekâsının gücünün nereye kadar ulaştığını, ne gibi objeleri kavrayabileceğini, hangilerinin bu kavramanın dışında kaldıklarını araştırmaya karar vermiş ve böylece batı felsefe tarihinin kilit eserlerinden biri sayılan ve yirmi yıllık bir çalışmanın ürünü olan İnsan Anlığ Bir Deneme (An Essay Concerning Human Understanding) adlı kitabını yazmıştır (Tokatlı, 1973: 240-241).

$\mathrm{Bu}$ araştırmada İbn Haldun'un bilgi anlayışı daha çok "Mukaddime" isimli eseri temel alınarak ve onunla ilgili yapılan çalışmalar; J. Locke'un epistemolojisi de öncelikle "İnsan Anlığl Üzerine Bir Deneme" ve kısmen diğer eserleri ve onunla ilgili yapılan çalışmaların içerik çözümlenmesi yöntemi ile çıkartılmaya çalışılmıştır.

\section{A. İnsan Herhangi Bir Bilgiye Sahip Olarak Doğmaz.}

Hem İbn Haldun hem de J. Locke idealizm ve rasyonalizmdeki gibi insanın doğuştan bir takım bilgiler getirdiğini kabul etmezler. İbn Haldun'un epistemolojisinin temel önermesi "insan doğası bakımından cahil kazandığ bilgi ve sanat bakımından âlimdir" sözüdür (İbn Haldun, 2004: C. I, 772, 775). Burada onun insan doğasının iki önemli yönüne; doğuştan getirdiği ve sonradan edindiği özelliklere dikkat çekmekte olduğu görülmektedir. Buna göre insan doğduğunda herhangi bir bilgiye sahip değildir, bilgi sahibi olma bakımından o cahildir, bir başka deyişle bilgiden yoksundur, repertuarında bilinçli olarak öğrenilmiş bilgiler yoktur.

Ancak, insan doğduğunda herhangi bir bilgiye sahip olmamakla beraber bilgiyi sonradan edinebilecek donanıma sahip olarak doğar, İbn Haldun Allah'in hayvanlardan her birine kendilerini savunmaları için bir organ verirken insana da fikir ve el verdiğine (İbn Haldun, t. y: 42) dikkat çeker. Ona göre, fikir insanın kendini gerçekleştirmesine yarayan ve onu diğer hayvanlardan, canlılardan ayıran ve üstün kılan bir güçtür (İbn Haldun, 2004). İnsanın bu gücü ve yetenekleri belli bir olgunluğa erişip geliştirilince bilgiyi sonradan edinir ve edindiği bilgiler sayesinde kendini gerçekleştirir.

Fakat insanın bilgi edinmek için de belli bir zihinsel olgunluk düzeyine ulaşması gerekir, bu zihinsel olgunluk düzeyine İbn Haldun "temyiz" der. Öğretimin başlangıç yaşı olarak kabul edilen temyiz çağından önce İbn Haldun bireyin hiçbir bilgiye sahip olmadığını, bu nedenle hayvanlardan sayıldığını, yaratılış itibariyle kaynağı olan nutfe, kan pıhtısı ve et parçası hükmünde bulunduğunu ileri sürer. Birey bu çağdan itibaren Allah'ın kendisine verdiği duyu organları ve fikir ile bilgi edinmeye başlamakta ve böylece kazandığ 1 ilimle onun varlığ 1 yetkinliğe ulaşmaktadır (İbn Haldun, 2004: C. II, 775). 
Aslında İbn Haldun'un çocuğun öğretim yaşından önce hiçbir bilgiye sahip olmadığ 1 düşüncesi tamamen doğru olarak kabul edilemez, çünkü çocuk bu yaştan önce de duyuları ile birtakım bilgiler edinir, ayrıca çok küçük yaşlarda spor ve müzik eğitimine başlayan çocukların olduğu da bilinmektedir. Belki burada İbn Haldun'un kastettiği çocuğun bilinçli olarak herhangi bir şeyin bilgisine sahip olamayacağıdır. Çocuğun bilişsel ve duyuşsal gelişimi henüz tamamlanmadığından öğretim yaşından önce daha çok taklit ve model alma yoluyla öğrenir ve İbn Haldun'a göre fikir ile bilgi edinmesi henüz mümkün olamamaktadır. İnsanın kendini gerçekleştirmesi ve varlığının yetkinliğe ulaşması ayırt edici bir özelliği olan fikir ile bilinçli olarak edindiği bilgiler sayesinde mümkün olur, bu da birden gerçekleşmez. İnsanın gelişimi ve kendini gerçekleştirmesi yaşam boyu kesintisiz devam eden uzun bir sürece yayılır ve bu süreç de öğretim yaşından itibaren başlar.

Anlaşıldığ1 kadarıyla İbn Haldun doğduğunda insanın herhangi bir bilgiye sahip olmadığını ancak bilgi edinmeyi mümkün kılacak donanıma sahip olduğunu ve bu donanımın da öğretim yaşından itibaren yeterli olgunluğa ulaşmaya başladığını kabul etmektedir. Buna göre, başlangıçta bir kan pihtısı, et parçası olan insan kendisine potansiyel olarak verilmiş bilgi edinme güçleri geliştirilerek iyiyi kötüden ayırt etme yaşı olan öğretimin başlangıç yaşından itibaren eğitim ve öğretim ile kendini gerçekleştirmeye başlar. İnsanın kendini gerçekleştirmesi veya İbn Haldun'un deyişiyle kemâle ermesi birden gerçekleşmez, bu belirli aşamalardan oluşan bir süreçtir.

$\mathrm{Bu}$ sürecin temelinde iyiyi kötüden ayırt etmeye yarayan akıl (temyizî akıl) en üstte ise kuramsal akıl (nazarî akıl) bulunur ve İbn Haldun onların işlevlerini şu şekilde açıklar: "Fiillerin meydana gelmesine temel olan iyiyi kötüden ayırt etmeye yarayan akıl ile birey işlerini düzgün bir şekilde meydana getirmesini öğrenir; daha sonra bunun üzerinde yer alan, deneylerle kazanılan deneysel (tecrübî) akıl ile görüşlere, faydalı ve zararlı işlere ait bilgiyi hemcinsinden alır; kendini gerçekleştirme sürecinin en üstünde yer alan kuramsal akıl ile de madde ve fizik ötesi âlemdeki görünen ve görünmeyen varlıkların düşüncelerini edinebilir" (İbn Haldun, 2004: C. II, 775). Ancak bu aşamaların hepsi herkeste gerçekleşmeyebilir, söz konusu bu süreç her insanda piramidin en üst noktasına da ulaşmayabilir. Ancak bilişsel ve duyuşsal yönün normal gelişim seyrinde aklın gelişimi ve olgunlaşması mümkün olabilmektedir, bunun için yapılması gereken ise bu yetilerin üstü kapatılmadan bireyin gelişimi için uygun bir çevrenin ona sağlanmasıdır. Bu da bireyin gelişim ve dönüşümünde eğitim-öğretimin oynadığ 1 rolü kendiliğinden ortaya koyar. 
İbn Haldun akı1 ile fikir kavramlarını eş anlamda kullanmaktadır. Onun bilgi anlayışında fikir anahtar bir kavramdır ve merkezî bir önem sahiptir. Çünkü fikir insanın algılanan şeyleri sebep sonuç ilişkileri kurarak birbirine bağlamasına (İbn Haldun, 2004) ve bireysel ve toplumsal hayatını organize ederek devam ettirebilmesine de olanak sağlayan bir yetidir. Bazen de fikir istenilene yönelerek önceden zihinde var olmayan bir ilmin meydana gelmesinin kaynağı ve başlangıç noktasını oluşturur (İbn Haldun, t. y: 534535). İbn Haldun'un görüşlerinden insanın farklı türden bilgiler edinmesini sağlayan aklın veya fikrin bireysel boyutunun yanında, toplumsal ve kuramsal bir boyutunun da olduğu ortaya çıkar. Akıl bireysel boyutu ile olay ve olguları anlama ve anlamlandırmaya çalışırken, toplumsal boyutuyla sosyal çevrede ve kurumlarda eğitim yoluyla bilgi, değer ve normlar kazanırken, kuramsal boyutu ile de varlık hakkında bir düşünce geliştirir ve özü kavramaya çalışır. Fakat bunlar analitik ayrımlardır, pratikte ise deneysel ak1l ile kuramsal akıl birbirini etkilediklerinden birbirinden ayırt edilemezler (Canatan, 2006: 58).

Burada vurgulanması gereken bir başka konu da İbn Haldun'un epistemolojisinde doğası bakımından cahil olan insanın öğretim çağından itibaren taklit ve model alma ile öğrenmeden kurtulup, bilinçli ve aktif bir şekilde bilgi edinme eylemi içine girerek hayvandan farklılaşmaya ve ayırtedici özelliklerine sahip olmaya başlamasıdır. Birey bu süreçte edindiği bilgileri içselleştirip hayata geçirerek bilişsel, duyuşsal ve psikomotor yönünü köklü bir dönüşüme uğratır.

Locke da İbn Haldun gibi insanın doğuştan bir takım fikirler getirdiğine karşı çıkar ve zihni bütün özniteliklerinden yoksun beyaz bir kâğıt olarak düşünür. Bir bilginin nasıl edinildiğinin gösterilmesi onun doğuştan olmadığını kanıtlamaya yeter (Locke, 1997: 59) diyerek doğuştan getirilen fikirlerin olmadığını açıklamaya çalışan Locke (1997: 59-60)'a göre en büyük kanıt, bütün insanların kabul ettiği belli teorik ve pratik ilkelerin bulunduğu genel kabulüdür. Genel kabul hiçbir şeyin doğuştanlığını kanıtlamaz, ayrıca bütün insanlığın anlaşmaya vardığı hiçbir genel ilke de yoktur.

Doğuştan getirilen teorik ilkelerin bulunmadığ 1 gibi pratik ilkelerin de olmadığını kanıtlamaya çalışan Locke ahlâkî eğitim-öğretim sayesinde iyi bir ahlâk ve nezaket kazanmış insanlar arasında ahlâkla ilgili olarak kesin ve şüpheden uzak bir takım görüşler bulunduğunu kabul ettiğini, fakat bunların öğrenildiğini ileri sürer (Locke, 1999: 38-39).

Locke (1997: 59-60)'a göre, Descartes'1n ileri sürdüğü gibi zihne doğal olarak basılmış (nakşedilmiş) fikirler de yoktur. Burada doğuştan fikirler 
görüşü ile kastedilen, ruhun başlangıçta kazanmış olduğu ve kendisiyle beraber dünyaya getirdiği sanki insan zihnine basılmış gibi bulunan bir takım temel fikirler, önsel (a priori) kavramlar ve özelliklerdir.

Doğuştan kavramların, ilkelerin ve idelerin varlığını kabul etmeyen Locke bunların niçin doğuştan olduklarının kabul edildiğinin gerekçesini şu şekilde açıklar: Ona göre, insanlar kendilerinden şüphe edilemeyen genel önermeleri bulunca bunların doğuştan olduğunu söylerler, çünkü bu en kolay ve en kestirme yoldur. $\mathrm{Bu}$ bir kez kabul edilince tembeli araştırma sıkıntısından, şüpheciyi de soruşturma zahmetinden kurtarır ve böylece onları kendi akıl ve yargılarını kullanmaktan alıkoyar ve bu kişiler o öğretilere inanmak ve onları yeniden incelemeden inanç yoluyla kabul etmek zorunda kalırlar. Oysa insanların birçok evrensel doğrulara nasıl eriştikleri incelenmiş olsayd, bunların inceleme sonucu ve uygun olan insan yetilerinin uygulanması yoluyla öğrenildiği anlaşı1ırdı (Locke, 1997: 106).

Görüldüğü gibi her iki düşünür de insanın sahip olduğu bilgiler ve ilkelerin doğuştan getirildiğini kabul etmezler. İnsan doğduğunda herhangi bir bilgiye sahip olmamakla beraber bilgi edinebilecek bir donanıma sahip olarak doğar. Ancak bu yetiler bilinçli olarak bilgi edinebilecek bir olgunluğa öğrenim yaşının başlangıcı kabul edilen yaklaşık yedi yaşında erer. $\mathrm{Bu}$ yaşa kadar taklit ve model alma ile öğrenen çocuğun bu yaştan itibaren "niçin" sorusu ile şeylerin varlık nedenini araştırmaya başladığ görülür. Önceleri kolay inanan ve zihinsel benmerkezciliğin etkisi ile tepkisel davranışlarda bulunan çocuk yedi ya da sekiz yaşından itibaren hareket etmeden önce düşünmeye ve atomistik açıllamalar yapmaya başlar (Piaget, 2004). Zihinsel gelişimde kesin bir dönemeci oluşturan yedi yaş (Piaget, 2004: 57) çocuk için bilinçli bilgi edinmenin başladığı dönemdir ve birey bu yaştan itibaren başlayan ve yaşam boyu devam eden bilinçli olarak edindiği bilgiler ile varlığını gerçekleştirir.

Gerek İbn Haldun'da gerekse J. Locke'da eğitim-öğretimin bireyin değişim ve dönüşümünde etkin bir araç olarak kabul edildiği sonucunun çıkartılabileceği bu bölümde her iki düşünürün epistemolojisinde eğitim felsefesine temel oluşturabilecek olan önemli anahtar kavramlar ve konuların ele alındığı görülmektedir. Bunlar tabula rasa veya zihnin doğduğunda boş bir levha gibi olması, fikir, doğrunun yanlıştan ayırt edilmeye başlandığ 1 dönem olan öğrenim yaş1 (temyiz), doğruyu yanlıştan ayırt edebilen akıl, genel deneyimler edinebilen tecrübî akıl, soyut düşünebilen kuramsal akıl ve insanın varlığını gerçekleştirmesinin birden olmayıp yaşam boyu süren bir sürece yayılmasıdır. 
Her iki düşünürün epistemolojisinde başlangıç noktası olarak aldığımız "insanın bilgiler ile değil ancak bilgi edinmeye olanak sağlayacak donanım ile doğması" konusunda eğitim-öğretimin önemi ve gücü açıkça görülür. $\mathrm{Bu}$ sonuca ulaştıran temel dayanaklar şunlardır:

Birincisi, İbn Haldun'un bilgi anlayışında doğası bakımından cahil olan insan kazandığ 1 bilgi ve sanat ile cehaletten kurtulup bilgi sahibi- âlimolabilmektedir. Bilgilerin ve sanatların kazanılması ise onların öğrenilmesi, kişiye mal edilmesi veya içselleştirilmesi ve hayata geçirilmesi ile mümkün olur. Bu da formal ve informal eğitim-öğretim ile gerçekleşebilir. İkincisi, yine İbn Haldun'un epistemolojisindeki insanın bireysel, toplumsal ve kuramsal boyutları bulunan fikir gücü ile olay ve olguları anlama ve anlamlandırmaya; bireysel ve toplumsal hayatını organize ederek devam ettirebilmesine yarayacak bilgi, değer ve normlar edinmeye ve varlık hakkında bir düşünce geliştirip özü kavramaya çalıştığ 1 görüşüdür. İnsanda potansiyel olarak bulunan fikir-akıl gücünün bu işlevlerini yerine getirebilmesi için onun formal ve informal eğitim-öğretim ile geliştirilmesi gerekir. Yaşamda örneklerine sıkça rastlayabileceğimiz gibi kendisinde potansiyel olarak var olan güçlerinin çoğu veya bir kısmı formal veya informal eğitim ile geliştirilemeyen bir çok insanın tam olarak kendilerini gerçekleştiremedikleri görülür. Veya bazı kişilerin yetilerinin bir kısmının geliştirildiği alanlarda yetkin olduğu diğer alanlarda ise şaş1lacak derecede geri kaldığını gözlemek mümkündür.

J. Locke'un epistemolojisinden gösterilebilecek temel dayanaklardan birincisi ise, insanların sahip olduğu ahlâkî ve görgü kurallarının doğuştan olmayıp eğitim-öğretim sayesinde öğrenildiği görüşüdür. İkincisi de, onun "insanların birçok evrensel doğrulara nasıl eriştikleri incelenmiş olsaydı, bunların inceleme sonucu ve uygun olan insan yetilerinin uygulanmasi yoluyla öğrenildiği anlaşılırdı" ifadesidir. İnceleme ve uygun olan insan yetilerinin uygulanması da ancak formal ve informal eğitim-öğretim ile bilişsel, duyuşsal ve psikomotor yetilerin geliştirilerek kazanımlar elde edebilecek hale gelmesi ile mümkün olabilir.

İbn Haldun'un bilgi anlayışındaki fikir kavramı, fikrin fonksiyonları ve insanın kendini gerçekleştirmesinin birden olmayıp, kesintisiz devam eden tüm yaşama yayılması da eğitim felsefesinin temelleri arasında yer alabilecek önemli konulardandır. Fikir veya akıl, aklın geliştirilmesi hem geleneksel, hem modern, hem de postmodern eğitim anlayışında güncelliğini ve önemini koruyan bir konudur. Eğitim, eğitim felsefesi ve eğitim psikolojisinin bilişsel öğrenme ile ilgili bölümünde bu konu ile ilgili çeşitli teoriler geliştirilip, uygulanmaya çalışılmıştır ve günümüzde de konu ile ilgili çeşitli çalışmalar devam etmektedir. Zihin eğitimine ve aklın 
geliştirilmesine önem veren rasyonalizm, idealizm, aktif öğrenme, eleştirel düşünme ve yaratıcı düşünme ile ilgili çalışmalar gösterilebilecek örneklerden birkaçıdır. Yaşam boyu eğitim-öğretim ise yetişkinlerin yeni bilgiler ve beceriler edinerek gelişim ve değişimlere uyum sağlayabilmeleri, değişen teknolojiyi etkin bir şekilde kullanabilmeleri, alanlarında kendilerini güncelleyebilmeleri ve bilimsel ve teknolojik gelişmeler işığında bilgi ve değer üretebilmelerine yardımcı olmayı amaç edinen güncelliğini koruyan bir eğitim modelidir.

\section{B. Bilginin Kaynağı ve Oluşumu}

İbn Haldun'da bilginin kaynağı duyular ve akıl ile eş anlamda kullandığı fikir; J. Locke'ta da duyum ve düşünümdür. İbn Haldun'a göre dışarıdaki nesnelerin algılarının zihne akışı duyularla gerçekleşir (İbn Haldun, 2004, C. II), ancak duyuların zihne akışını sağladığı duyu verileri bilgi değildir yalnızca bilginin hammaddeleridir, bunlar iç duyular tarafından çeşitli işlemlerden geçirilerek bilgi haline gelir. O, nefsin idrak kuvvetinin görünen ve görünmeyen organları (İbn Haldun, t. y: 97) olarak tanımladığ 1 duyuları iç duyular ve dış duyular diye ikiye ayırır. Nefsin görünen organları olan diş duyular beş tane olup bunlar ile görünenler idrak edilirken, nefsin görünmeyen organları olan iç duyular ile de görünmeyenler idrak edilir.

Zihni başlangıçta beyaz bir sayfa gibi düşünen ve önsel kavramlar, ilkeler ve idelerin bulunmadığını ileri süren ve bunu kanıtlamaya çalışan J. Locke da "o halde bunlar nereden gelmektedir? Bu zihin nasıl dolacak, zihin akıl ve bilginin bütün gereçlerini nereden edinmiştir?” (Locke, 1996: 86) diye sorar ve bu sorusunu da "bütün ideler ya duyumdan ya da düşünümden gelmektedir" şeklinde yanıtlar. Buna göre idelerin kaynağı duyum (sensation) ve düşünüm (reflection) olmak üzere ikiye ayrılır, o bunları dış duyum ve iç duyum diye de adlandırır. Bilginin ortaya çıkabilmesi için gerekli olan duyum ve düşünümün her ikisi de doğuştan değildir ve bunların temelinde deney vardır. Buna göre bilginin kaynağı deneydir, zihin akıl ve bilginin bütün gereçlerini deneyden edinir. Dolayısıyla bütün bilgilerimizin temelinde deney bulunur ve bilgilerimiz oradan türer (Locke, 1997).

J. Locke duyumları belli zihinsel görüntüler şeklinde tanımlarken (Russell, 1970: 227) zaman zaman "akıl" kavramı ile ifade ettiği düşünümü de ruhun bilinen şeylerden bilinmeyen şeylere doğru ilerleyen ve önermelerin belli ve düzenli bir dizilişi içinde bir şeyden başka bir şeye delil getiren düşünme yetisi (Locke, 1999: 43) şeklinde tanımlar. Aslında İbn Haldun'un iç duyular dediği şey ile J. Locke'un düşünüm dediği şey birbirinden çok da farklı değildir, ikisinin de aklın fonksiyonları olduğu söylenebilir. İbn Haldun'un iç duyuları, duyularla ulaşılan duyu verilerini bir 
bütün halinde algılayan güç (müşterek his), duyu verilerini dışarıdaki maddelerinden ayırıp soyutlayarak şekil veren ve zihne imajlarını yerleştiren hayal gücü (muhayyile), somut ve bireysel şeylerle ilgili anlamları idrak eden güç (vâhime), bellek (hafiza) ve fikirdir (nefs-i nâtıka). Locke'un düşünümü de algılama, hafıza, ayırdetme, birleştirme, genişletme ve soyutlama gibi zihinsel işlemlerden oluşur (Locke, 1997).

İbn Haldun'un bilgi anlayışında bir sıraya göre dizilen bu idrak kuvvetlerinin en altında görme, işitme gibi duyu organları, bunun üzerinde duyularla ulaşılan görülmüş, işitilmiş, dokunulmuş vb. duyu verilerini bir bütün halinde idrak eden güç bulunur. $\mathrm{Bu}$ güç kendisindeki algıları hayal gücüne gönderdiğinde hayal gücü bunları dışarıdaki maddelerinden ayırıp soyutlayarak bir şekil verir ve zihne imajlarını yerleştirir. Hayal gücünün üzerinde yer alan nefsin idrak kuvvetleri somut ve bireysel şeylerle ilgili anlamları idrak eden güç (vâhime) ve bellektir. Vâhime somut ve bireysel şeylerle ilgili anlamları idrak ederken hafıza da idrakler için depo görevini görür, daha sonra bütün bunlar fikir kuvvetine yükselir (İbn Haldun, t. y: 97; 104).

Görüldüğü gibi, zihinde işlenecek herhangi bir hammadde olmadan bilgi üretilemeyeceğinden dışarıdaki nesnelerin algılarının zihne akışını sağlayan duyular hem İbn Haldun hem de J. Locke için bilgi kaynaklarından ilkidir, çünkü iç duyular dış duyuların algıladığı ve zihne taşıdığg veriler üzerinde işlemler yaparlar. Bu nedenle iyi bir öğrenmenin gerçekleşebilmesi veya herhangi bir konuda kalıcı bir bilgiye sahip olunabilmesi için öncelikle duyuların sağlıklı gelişimine önem verilmesi gerekir.

Bütün bunlardan anlaşıldığına göre, İbn Haldun'un epistemolojisinde dış duyular aracılığı ile zihne bilginin hammaddesi olan alg1 akış1 gerçekleşir, daha sonra bu algılar iç duyular tarafından çeşitli işlemlerden geçirilerek bilgiye dönüşür: Dış duyuların algıları üzerinde ilk işlemi "müşterek his" yapar, bu zihinsel güç ayrı ayrı algılanan şeyleri bir bütün halinde algılar ve bu algıyı hayal gücüne gönderir. Hayal gücü bu algıları dışarıdaki maddelerinden ayırıp soyutlar ve bunların imajlarını zihne yerleştirir. Bir sonraki aşamada vâhime anlamları algılar, bir başka ifade ile algıların anlam kodlarını çözer; bellek de iç duyular ile çeşitli işlemlerden geçen algıları depolar. İbn Haldun bütün bunların daha sonra fikir kuvvetine yükseldiğini söyler. Fikir İbn Haldun'a göre gerçeği kavramanın doğal aracıdır ve doğru hüküm vermek onun ile mümkündür (İbn Haldun, t. y: 535-536). Bir başka deyişle fikir, duyu verilerinin iç duyular tarafindan çeşitli işlemlerden geçirilerek onlar hakkında bilgi edinilmesi; bir anlama sahip olunarak o konunun anlaşılması, anlamlandırılması ve bir yargıya varılmasını sağlayan güçtür. Daha sonra bilgiden bilgi üretilerek bilgi 
edinme, anlamlandırma ve değerlendirme süreçlerinin başka alanlara taşınması da fikirle olur.

İbn Haldun'un fikir kavramı ile ilgili açıklamalarından iç duyular diye gruplandırdığg müşterek his, muhayyile, vâhime ve hafizanın, daha önce de değinildiği gibi, fikrin güçleri, bir başka ifade ile aklın fonksiyonları olduğu anlaşılır.

İbn Haldun'un bilgi anlayışındaki bilginin oluşum süreci Locke'un epistemolojisinde de şu şekilde gerçekleşir: İdelerin ilk kaynağ 1 olan diş duyum sürecinde duyular önce belli nesnelere yönelerek bunlardan çeşitli şekillerde aldıkları birçok seçik algıları zihne iletirler ve böylece sarı, ak, sıcak-soğuk, yumuşak-sert, ac1-tatlı gibi idelerle, duyulur nitelikler denilen öteki niteliklerin idelerine sahip olunur (Locke, 1997: 109). Bir başka deyişle insan ilk duyumu edindiğinde ilk ideye de sahip olur (Locke, 1997). Düşünüm sürecinde de duyu nesnelerinin çoğunun özel ideleri, bir aynanın karşısına konulan şeylerin hayalinin reddedilemediği, değiştirilemediği veya silinemediği gibi, istense de istenmese de zihne girerler ve zihin bunlar üzerinde algilama, hafizaya kaydetme, ayırdetme, birleştirme, genişletme ve soyutlama gibi işlemleri gerçekleştirir ve zihin bu idelerin ötesine geçemez (Locke, 1997: 120-121). Yani Locke'a göre ilk ideler zihne ulaşır ulaşmaz zihnin bu yetileri kendiliğinden çalışmaya başlar ve bundan çıkan sonuca göre, daha önce duyuda bulunmayan hiçbir şey zihinde yer alamaz (Locke, 2004).

İbn Haldun'un fikrin dereceleri ve işlevleri ile ilgili görüşlerinden de bilginin oluşum süreci hakkında bilgi edinmek mümkündür. $\mathrm{O}$ bu süreçteki işleyişi şu şekilde anlatır:

"Fikrin birinci derecesi, insanın kendi dışındakileri ve onlardaki düzeni aklen kavramak ve kendi dışındaki objelerin önce imajlarını çıkartmak, sonra da onlarla ilgili kavramlar oluşturmaktır (tasavvur). İkincisi, insanın toplumsal ilişkilerini sürdürmesini sağlayan ve görgü kurallarını kazandıran fikirdir (tasdik). Fikrin üçüncü derecesi de, duyularla algılamanın ötesinde olan, pratik ile bir ilgisi bulunmayan bir amaç hakkında ilim veya zan meydana getiren fikirdir. Böylece fikir kavram oluşturarak ve yargıda bulunarak kendi cinsinden olan başka bir bilgiyi, sonra farklı bir şekilde düzenleme ve birleştirme ile ayrı bir bilgiyi ve aynı şekilde diğer bir bilgiyi meydana getirir" -bilgiden bilgi üretir- (İbn Haldun, 2004, C. II, 766-767).

Özetle, ilimleri ve sanatları idrak eden bir araç olan fikrin işleyişi, ya türleri bir bütün oluşturacak şekilde bir araya toplayıp, zihinde dışarıdaki varlıklara karş11ı gelen bir şekil (kavram) oluşturarak somut ve belirli 
şeylerin içeriğini bilmek veya bir şeye diğer bir şeyle hükmetmek şeklinde olur (İbn Haldun, t. y: 490).

Görüldüğü gibi İbn Haldun bilgiyi "tasavvur" ve "tasdik" olmak üzere ikiye ayırır, "tasavvur"u kavram oluşturmak ve şeylerin özünü kavramak; "tasdik"i de bilgiden bilgi üretmek ve yargı karşılığı kullanmaktadır. Onun bilginin tasavvur ve tasdik diye ikiye ayrılması konusunda meşşâi filozofları gibi düşündüğü söylenebilir. Bilginin veya düşüncenin tasavvur ve tasdik olarak ikiye ayrılması Aristoteles'te görülür, Aristoteles tasavvuru yarg1 içermeyen düşünce; tasdiki de yargı içeren düşünce olarak tanımlar (Türker, 2002: 113). Meşşâî filozoflarından Farabî de bu ayrımı kullanır ve insan aklının iki eyleminden biri olan tasavvuru zihnin basit kavramları, onların temel özelliklerini tanımlamak amacıyla ortaya çıkan düşünce; tasdiki de doğrudan doğruya bileşik kavramları ve bunların doğruluk ve yanlışlığının doğrulanması ile ilgili düşünce olarak tanımlar (Adamson ve Taylor: 2008: 75). Bunlara dayanılarak "tasavvur"un basit kavrama, yanlışlığı veya doğruluğu konusunda bir fikir vermeyen bilgi, "tasdik"in de bir hüküm içeren bilgi olduğunu söylemek mümkündür.

J. Locke bilgiyi iki ide arasındaki bağlantı ve uyuşma ya da karşıtlık ve uyuşmamanın algılanması olarak tanımlar. İdeler arasındaki uyuşma da özdeşlik ya da başkalık, bağıntı, birlikte var oluş ya da zorunlu bağlantı ve gerçek var oluş olmak üzere dört türe indirgenebilir (Locke, 1997: 467). Bilgiye ulaşmak için idelere sahip olmanın yanı sıra bunlar arasındaki uyuşma ve karşıtlığın da algılanması gerekir.

Locke (1999: 42-43)'a göre, ancak duyular ve akıl işbirliği içerisinde çalışır; duyu yetisi akıl için duyulur nesnelerin idelerini ve düşünmenin malzemelerini sağlar, akıl da duyu yetisine rehberlik eder, varlıkların duyu algısıyla elde edilen kopyalarını düzenler, onlardan hareketle yeni kopyalar oluşturursa, o zaman her şeye gücü yeten zihnin kendi içine yönelme ve düşünme ile kavrayamayacağı bir şey olmaz. Ancak duyuların yardımı ve hizmeti olmadan düşünümün temel malzemesi eksik olacağından, akıl ancak panjurları kapatılmış bir pencerenin arkasında, karanlıkta çalışan bir işçinin gerçekleştirebileceği kadar başarı elde eder; akı1 olmadan da duyular harekete geçirilse bile en fazla hayvanların düzeyine ulaşılabilir. Çünkü maymun gibi birçok dört ayaklı hayvanın duyularının insanlardan çok daha üstün olduğu bilinmektedir. Locke'un akıl olmadan yalnızca duyular ile hareket eden insanın en fazla hayvanlar düzeyine erişebileceği görüşü İbn Haldun'un bilgi anlayışında da yer alır. "İnsan Herhangi Bir Bilgiye Sahip Olarak Doğmaz" başlıklı bölümde geniş bir şekilde açıklandığı gibi İbn Haldun epistemolojisinde de birey bilgi edinme ve kendini gerçekleştirme aracı olan fikirden yoksun olduğunda hayvanlardan sayılır. 
Kant'a (1724-1804) kadar bilginin duyarlık ve zihnin ortak çalışmasının bir ürünü olduğu kabul edilmiştir fakat Kant duyarlık ile zihni birbirinden ayırarak bilginin bu ikisinin ortak çalışmasının değil, zihnin duyarlıktaki malzemeyi işlemesi ve biçimlendirmesinin bir ürünü olduğunu ileri sürmüştür. "Yani bilgi, zihnin önceden sahip olduğu olanakların duyusal malzemeye taşınması ile (Kant'ın sözleri ile: aklın a priorilerini nesnelerin içine sokması ile) oluşur." (Diemer, 2001: 174). İbn Haldun da daha önce belirtildiği gibi duyuları dış duyular ve iç duyular olarak ikiye ayırır. Dış duyular ile algılananlar üzerinde iç duyular aracılığı ile bir takım zihinsel işlemler gerçekleştirilerek bilgi üretilir. Bilgi üreten bu güç fikirdir, fikir de fizikî ve biyolojik gelişmeden sonra öğretime başlama yaşında meydana gelir (İbn Haldun, 2004, C. II.), Öğretime başlama yaşından önce bireyin hiçbir bilgiye sahip olmaması fikrin, dolayısıyla onun araçları olan iç duyuların henüz bilgi üretecek olgunluğa ulaşmamasındandır. Bütün bu görüşlere dayanılarak İbn Haldun'un bilgi anlayışında da bilginin duyu malzemeleri üzerinde fikrin iç duyular aracılığı ile yaptığı işlemler sonucu elde edilen bir ürün olduğunu söylemek mümkündür.

İbn Haldun ve J. Locke'un epistemolojisinde bilginin kaynăg ile ilgili bölümde de eğitim felsefesine temel oluşturabilecek önemli görüşler vardır. Bilginin kaynağı ve iç duyuların işleyişi, bir başka ifade ile bilginin oluşum süreci ile ilgili olan bu görüşler eğitim felsefesinin uğraşı alanlarıyla ilgisi bakımından önem taşımaktadır.

Her iki düşünür için de bilginin birinci kaynağını oluşturan duyular eğitim-öğretim etkinliklerinin girişi konumundadır. Çünkü duyular dış dünyaya açılan pencerelerdir ve zihne dış dünya ile ilgili verilerin akışı, girdinin sağlanması onlar ile mümkün olur. Duyular yeterli olgunluğa ulaşmadığında veya herhangi bir nedenden dolayı işlevlerini yerine getiremediklerinde eğitim-öğretim etkinliklerinin gerçekleştirilmesi de olanaksız hale gelebilir. Alıcı kapalı olduğunda iletişim sisteminin diğer ögeleri ne kadar gelişmiş olursa olsun işe yarayacakları söylenemez, bundan dolayı duyuların sağ lıklı gelişimine önem verilmesi gerekir.

Ancak duyular gelişimi tamamlanmış olsa da eğitim-öğretim için tek başına yeterli olamazlar, İbn Haldun ve Locke'un ifadeleri ile fikirden yoksun olunduğunda, akıl olmadan duyular harekete geçirilse bile en fazla hayvanların düzeyine ulaşılabilir. Bu nedenle bilginin üretilebilmesi veya eğitim-öğretimin gerçekleştirilebilmesi için eğitim-öğretimin temelini oluşturan duyuların ve aklın işbirliğine ihtiyaç vardır. Eğer aklın işleyişi tam olarak bilinirse öğrencilerin bu yetileri geliştirilerek daha etkili ve kalıcı bir öğrenmenin gerçekleşmesine katkıda bulunulabilir. Zihnin öğelerini ve bunların işleyişini bilen bir öğretmen öğrencilerin zihinsel yetilerini ve 
problem çözme, eleştirel, yaratıcı düşünme, vb. güçlerini geliştirmek için eğitim-öğretim etkinlikleri düzenler.

İbn Haldun'un iç duyular ve J. Locke'un düşünüm ile ilgili görüşleri daha çok son yıllarda felsefe, eğitim ve psikolojinin araştırma alanlarından birini oluşturan yapılandırmacılığın bir türü olan psikolojik yapılandırmacılık ile ve ayrıca bilgilerin zihinde yapılandırılması ile kısmen benzediği söylenebilir. Bir başka deyişle İbn Haldun ve Locke'un iç ve dış duyular hakkındaki görüsslerinin yapılandırmacılığın epistemolojik temelleri arasında yer aldığını söylemek mümkündür.

Bu savın dayanaklarından ilki, psikolojik yapılandırmacılığın ilgilendiği konulardan birisinin de bireyin bilişsel öğelerini nasıl oluşturduğudur (Erden, Akman, 2006). Farklı türleri olan yapılandırmacılıkta eğitim, bilgileri zihinde yapılandırarak bireyin zihinsel yapısında değişme meydana getirme süreci olarak tanımlanır. Öğrenme de bilgilerin öğrenciye aktarılması ile değil, bilgilerin zihinde ișlenmesi, anlamlandırılması ve yapılandırılması ile gerçekleşir. Zihinde yapılandırma, bilgilerin üst üste yığılması, biriktirilmesi ve ezberlenmesi ile değil, düşünme, anlama, sorgulama ve sorun çözme yoluyla bilgiler arasında bağ kurulması ile olur (Güneş, 2010: 6).

İkinci dayanak ise, İbn Haldun'un epistemolojisinde dış duyular ile algılanan varlıklar hakkında iç duyular ile yargı içermeyen ve yargı içeren bilgi üretildikten sonra bilgi üretme işleminin burada sona ermemesi ve daha sonra da bilgiden bilgi üretilerek bilgi edinme, anlamlandırma ve değerlendirme süreçlerinin başka alanlara taşınmasıdır. J. Locke'da da zihnin düşünümün temel malzemesi olan basit ideleri bir kez biriktirince, bunları hemen hemen sonsuz bir değişiklik içinde yenileme, ölçüştürme ve birleştirme gücü de kazanarak kendince yeni karmaşık ideler yapabilmesidir (Locke, 1996: 95). Görüldüğü gibi her iki düşünürün bilgi anlayışındaki duyu verilerinin işlenerek bilgiye dönüştürülmesi ve bilgiden de başka bilgilerin üretilmesi süreci yapılandırmacılıktaki bilgilerin zihinde yapılandırılması ile hemen hemen aynidır.

Üçüncü dayanak ise J. Locke'un epistemolojisindendir. Locke zihnin bütün düşünce ve akıl yürütmelerinin dolaysız nesneleri olarak gözlemlediği ya da gözlemleyebildiği şeylerin yalnızca kendi ideleri olduğunu ve bütün bilgimizin onların çevresinde döneceğini ileri sürer. Locke'da bilgi ideler arasındaki bağıntının algılanmasıdır ve bilginin varlığı idelerin varlığına bağlıdır, dolayısıyla bilgi idelerin ve bunların arasındaki bağıntının algılanmasını aşamaz (Locke, 1997: 478-479) Bu şu demektir: Zihnin bütün düşünce ve akıl yürütmelerinin malzemesi yalnızca kendi ideleridir. Bilgi de 
ideler arasındaki bağıntının algılanması olduğuna göre, her zihnin donanımı farklı olacağından ürettiği bilgiler de özneldir. Radikal yapılandırmacılıkta da bilgi nesnel değil, özneldir ve bilenin zihinsel yapısına bağımlıdır. Ernst von Glasersfeld dış dünyada bireyden bağımsız nesnel bir gerçeklik olsa bile bireyin ona ait bilgisinin bu nesnel gerçekliği yansitamayacağını ileri sürer. Çünkü bilgi bireyin kendi deneyimleri tarafından oluşturulmuş, düzenlenmiş ve organize edilmiş bir dünyayı yansıtır (Aydın, 2007; Okumuşlar, 2008).

Hasan Aydın da Felsefí Temelleri Işı̆̆ı̆nda Yapılandırmacılık adlı eserinde yapılandırmacılığı felsefî açıdan temellendirmeye çalışan düşünürlerin yapılandırmacılığ 1 ontolojik ve epistemolojik temelleri açısından Aristoteles, Berkeley, Immanuel Kant, F. W. Nietzsche, Vico, J. Dewey, Thomas S. Kuhn ve L. Wittgenstein gibi düşünürlerin yanında J. Locke ile de ilişkili gördüklerini yazar. Fakat yine de anılan düşünürlerin hiçbirisinin felsefî anlayışının tümüyle yapılandırmacı anlayışa indirgenemeyeceğini de vurgular (Aydın, 2007: 23).

\section{Bilginin Konusu}

Duyu bilgileriyle düşünce ürünleri olan genel kavram veya tümelleri birbirinden ayıran İbn Haldun (t. y: 516)'a göre bilginin konusu tümellerdir, fakat bunlar cevher, beyazlık, başkalık, kardeşlik gibi her türlü soyutlamalar değil, varlıkta karşıllğı ve gerçek içeriği olan ağaç, insan gibi soyutlamalardır. Platon ve Aritoteles'in kavramları ile söylenecek olursa, bunlar Platon'un ideaları değil, Aristoteles'in somut ve gerçek bir içeriği olan "tür"leridir (Arslan, 1997: 377). Tümeller bilgiye kaynakl1k eden genel kavramlardır. Bütün ortaçağ boyunca devam eden tümeller tartışması bu genel kavramların dış dünyada gerçekliklerin olup olmadığı ile ilgilidir.

İbn Haldun filozofların varlıkların idraki ile ilgili görüşlerine yer verirken varlıkların algılanmaları sonucunda ulaşılan, duyu verilerinin soyutlanmasından elde edilen genel kavramlar ve ayrica bunların da tekrar soyutlanmasindan elde edilen daha genel kavramlardan söz eder. Duyu verilerinin soyutlanmasindan elde edilen genel kavramlar (birinci makullaer) tıpkı bir mührün, balçık veya mum üzerinde bıraktığı izler gibi dış dünyadaki varlıkların imajlarının ve anlamlarının soyutlanması ile ulaşılan kavramlardır (İbn Haldun, t. y: 516). Duyulur varliklardan soyutlanan bu kavramlara insan, ağaç, hayvan gibi kavramlar örnek olarak gösterilebilir, bunların gerçek dünyada içeriği vardır. Daha genel ve daha soyut olan kavramlar (ikinci makuller) ise bu soyut kavramlara dayanılarak bunlar üzerinde çeşitli zihinsel işlemler yapılarak onların da soyutlanması ile elde edilirler. Daha sonra elde edilen bu genel kavramlar daha başka kavramlar ile de karşılaştırılıp üzerlerinde analiz, sentez gibi zihinsel işlemler 
gerçekleştirilerek daha genel kavramlara ve sonunda kendilerinden daha öteye bir soyutlamanın olanaksız olduğu en yüksek türlere, en genel kavramlara ulaşılır. Dış dünyada karşıllı̆̆ 1 bulunamayan bu en genel ve en somut kavramlara (ikinci makuller) canlı, cansız, töz gibi kavramlar örnek olarak gösterilebilir.

İbn Haldun zihnin ikinci dereceden soyutlama ile elde ettiği cinsler, kategoriler ve en genel kavramlar olan tümellerin (ikinci makuller) dış dünyada hiçbir gerçekliği olmadığından dolayı bilimin konusunu oluşturamayacağını düşünür, bunlar tamamen zihinsel şeyler olduklarından dış dünyada nesnel hiçbir karşılıkları yoktur. Ona göre, birinci dereceden soyutlamalar olan genel kavramların (birinci makuller) dış dünyada karşılığ olduğu ve bilimin konusunu oluşturduğu ile ilgili Aristoteles ve Müslüman Aristotelesçilerin iddiaları doğrudur, geçerlidir. Bunlar vardırlar ve bilimin konusunu oluştururlar. İkinci ve daha üst derecelerde soyutlanan en genel ve en soyut kavramların ise diş dünyada somut herhangi bir gerçekliği olmadığından ve sözsel bir varlığa karşılık gelmeyip, yalnızca zihinsel soyutlamalar olduklarından bilimin konusunu oluşturamazlar (Arslan, 1997: 158-160).

İbn Haldun'a göre, duyu verilerinin soyutlanması ile ulaşılan kavramlar (birinci makuller) doğrudan doğruya dış dünyadaki varlıklardan oluşturulduklarından daha az soyut ve daha az genel olmaları, daha fazla duyusal içerik taşımaları ve dış dünyadaki nesnelere daha yakın olmalarından dolayı dış dünyadaki varlıklar ile daha çok uyumludurlar. Dolayısı ile bilginin konusunu da bunlar olmalıdır (İbn Haldun, t. y: 516), çünkü en genel kavramlar (ikinci makuller) daha soyut ve dış dünyadaki varlıklara daha uzaktır. Ancak İbn Haldun bilginin konusunu duyu verilerinden soyutlanan kavramların oluştuması gerektiğini kabul etse de dış dünyada algilanmayan, en genel ve en soyut şeylerin de yok sayılamayacağına ayrıca vurgu yapar.

Locke, "Zihnin, bütün düşünce ve akıl yürütmelerinin dolaysız nesneleri olarak gözlemlediği ya da gözlemleyebildiği şeyler yalnızca kendi ideleri olduğundan, bütün bilgimizin onların çevresinde döneceği açıktır" der. Ayrıca o bilgiyi ideler arasındaki bağıntının algılanması olarak tanımlar ve bilginin varlığının idelerin varlığına bağlı olduğunu, bilginin idelerin ve bunların arasındaki bağıntının algılanmasını aşamayacağını (Locke, 1997: 478-479) ileri sürer. Buna göre Locke'un epistemolojinde bilginin konusunun ideler ve ideler arasındaki bağıntılar olduğu anlaşılmaktadır.

Locke ideleri basit ve karmaşık ideler diye ayırır (Locke, 1997: 121). Zihin basit ideleri biriktirdiğinde bunlar üzerinde yenileme, ölçüştürme ve 
birleştirme gibi işlemler yapma gücü kazanır ve yeni, karmaşık ideler yapabilir. İdelerin ikinci türü olan bu karmaşık ideler zihnin iradeye bağlı olarak birçok basit ideleri birleştirmesiyle meydana gelir (Locke, 1997: 159160).

O, ideleri basit ve karmaşık olarak ayırmanın yanında açık-karanlık ve seçik-bulanık olarak da sınıflandırır. Ona göre, ideler iyi düzenlenmiş duyum ya da algı koşulları altında sunulduklarında açık, kaynaktaki doğruluklarında bir eksiklik bulunduğu ya da sanki zamanla solmuş veya kirlenmiş gibi, ilk tazeliklerini yitirdikleri zaman ise karanlıktırlar. İdelerin karanlık oluşu ya duyu organlarının duyarsızlığı ya nesnelerden gelen izlenimlerin silik ve geçici oluşu ya da hafizanın zayıflığından dolayı onları aldığ 1 gibi saklayamamasından ileri gelir. Seçik ya da bulanık ide ise şu şekilde tanımlanır: Bir idede onu diğer idelerden ayıran bir ayrım bulunursa seçik, diğer idelerden yeterince ayırt edilemeyen ide ise bulanıktır (Locke, 1997: 326-327).

Locke ayrıca ideleri gerçek-fantezi, upuygun-eksik ve doğru-yanlış ideler olarak da sınıflandırır. Gerçek varlıklar ve şeylerin var oluşlarıyla ya da bunların ilk örnekleri ile uyum içinde olmak gibi doğada bir temeli olanlar gerçek, bir temeli olmayan ve de uyum içinde olmayanlar da fantezi idelerdir. İlk örneklerini yetkin bir biçimde temsil edenler upuygun, eksik temsil edenler de eksik idelerdir (Locke, 1997: 334, 336-337).

\section{Bilginin Alanları}

İbn Haldun insanların bilgileri ile meleklerin bilgilerini karşılaştırırken insanın nefsinde üç bilgi âleminin varlığına şahit olduğunu ileri sürer: Birincisi, duyularla bilgisine ulaşılan fizikî âlem; ikincisi, duyu âleminin üzerindeki nefis ve zihin âlemi (fikr âlemi); üçüncüsü de varlığını içinde müşahede ettiği ve eserlerden çıkarsama yaptığı ruhlar ve melekler âlemidir (İbn Haldun, 2004: C. II, 770-771).

J. Locke'un epistemolojisinde ise bilgi alanları edimsel ve alışkanlıklar ile ilgili bilgi ve açıklı derecelerine göre de sezgisel, kanıtlamalı ve duyusal bilgi olarak sinıflandırılır.

İbn Haldun'a göre, fizikî alan dış duyular aracılığı ile bilinirken, zihinsel alan da fikir aracılığg ile yani içteki duyular ve duyu idrakinin üstünde bulunan, nefsin ilim idrak etme aracıları sayesinde bilinir. Ruhlar ve melekler alanı ise insanın varlığını içinde gözlemlemesi ve eserlerden çıkarsama yapması ile bilinebilir (İbn Haldun, 2004: C. II, 770-771). Zihinsel güçlerin ve yaşamın kaynağı olan nefsin (ruhun) bedene birleşmesi ile gerçekleşen aşağı yöne bağlantısında nefis duyular ile idrake alışırken, 
duyulardan kurtulan nefsin ruhanî âleme birleşmesi ile de ilmî ve fizik ötesi alana ait idrakler kazanılır (İbn Haldun, t. y: 96, 106) ve nefis kendisine özgü idrakle, idrak konusu şeylerin sadece bir sınıfını idrak edebilir (İbn Haldun, 2004, C. II, 955).

Aracısız elde edilen bilgi İbn Haldun'da ruhanî alanın bilgisidir ve bu alanın idrakinin belli şartlarda mümkün olabileceğini ileri süren İbn Haldun'a (1977: 41-42) göre duyuüstü idrak ancak duyuların devreden çıkması, durumunda mümkündür. Duyuların devreden çıtığı durumlardan biri uykudur (İbn Haldun, 1989: C. I, 255-257). Ruhanî alanın idrakinin meydana geldiği bir başka durum ruhsal arınma veya gayret gösterme ve çalışmadır. Ruhun manevi boyutu fizik ötesi alana dönerek orada bulunan varlıklara ait imajların kendisine aksetmesini sağlar (İbn Haldun, 1977: 110111). Ruhun sürekli gelişerek kendini gerçekleştirmesi his perdesinin açılmasına ve kendi varlığının gerçekliğini kavramasına sebep olur (İbn Haldun, 2004: C. II, 852).

İbn Haldun ruhanî alanın idrakinin belli şartlarda mümkün olduğunu kabul etmekle birlikte, insan aklının metafizik varlıklar hakkında kesin bilgi sahibi olamayacağını da vurgular; gerekçe olarak da metafiziğin duyuların ötesindeki varlıkları incelediğini ve bu alandaki varlıkların bilinemeyeceğini gösterir. Oysa insan aklı için ancak idrak alanına giren, dışarıdaki somut varlıklardan kavramlar oluşturmak mümkündür. İbn Haldun filozofların büyüğü Platon'un bile metafizik alan hakkında kesin bilgiye ulaşılamayacağını, yalnızca zandan bahsedilebileceğini söylediğine dikkat çekerek, "bunca yorgunluk ve çabalamadan sonra sadece bir zan elde edilecekse bu ilimlerin ve onlarla uğraşmanın faydası nedir?" diye sorar (İbn Haldun, 2004: C. II, 953). Ayrıca İbn Haldun'a göre, metafizik alan hakkında kesin bilgiye ulaşılamayacağının bir başka gerekçesi de nefsin (ruh) bütün ruhanî alanın bilgisini kuşatamayacağıdır, çünkü nefsin bu alandaki idraki sınırlıdır (İbn Haldun, 2004: C. II, 955).

J. Locke önce bilgiyi edimsel ve alışkanlıklar ile ilgili olmak üzere ikiye ayırır. Edimsel bilgi ideler arasındaki bağıntı üzerine zihnin şu andaki görüşü iken, alışkanlıklar ile ilgili bilgi de ideler arasındaki bağıntı bir kez zihinde ortaya çıktığında bunun her durumda, o uygun yönünün hiç duraksamadan görülüp kabul edilecek ve içerdiği doğruya güvenilecek biçimde hafizaya yerleştirilmesidir (Locke, 1997: 467-469).

Locke bilgiyi edimsel ve alışkanlıklar ile ilgili olanların yanı sıra açıklık derecelerine göre de sezgisel, kanıtlı ve duyusal olmak üzere üçe ayırır. Bu ayrım zihnin kendi ideleri arasındaki uyuşma ya da uyuşmamayı algılayışının değişik yollarından kaynaklanmaktadır. Örneğin, sezgisel bilgi 
zihnin ideler arasındaki bağıntıyı dolaysız olarak algılamasından, kanıtlı bilgi zihnin bu algılamada arac1 ideler kullanmasından, duyusal bilgi de zihnin diş-duyumla edindiği idelerden hareketle diş-duyuma konu olan varlıkların var oldukları sonucunu çıkartmasından oluşur (Locke, 1997: 471473). Locke'a (1996: 318) göre, gerçek varoluş yönünden kendimizinki için sezgisel, Tanrınınki için kanıtlamalı, başka herhangi şey için de duyusal bilgilerimiz vardır ve en dar alan duyusal bilgiye, en geniş alan da sezgisel bilgiye aittir.

Locke'a göre, idelerin birbirine göre olan bütün bağıntıları dolaysız olarak karşılaştırma yoluyla incelenemeyeceğinden sezgisel bilgi sahip olduğumuz bütün idelerimizin bağıntılarını kapsamaz. Örneğin, aynı iki paralel arasına ve aynı taban üzerine çizilmiş, biri geniş, diğeri dar açılı iki üçgen idesinin olduğu var sayıldığında, sezgisel bilgiyle bunların farklı olduğu algılanabilir, fakat onların eşitlik açısından uyuşup uyuşmadıkları dolaysız ölçüştürülmeyle algılanamaz. Bunun için onların kendilerine göre ölçüleceği aracı nicelikler gerekir ki, bu da kanıtlamalı ya da rasyonel bilgi olur (Locke, 1997: 478-479).

Kanıtlamalı bilgiye gelince, bilginin sınırları veya genişliği açısından, kanıtlamalı bilgide ideler arasındaki bağıntının anlaşılmasına yardımcı olacak aracı ide her zaman bulunmadığından, bir başka ifade ile ideler arasındaki ilişki kavranamadığından, kanıtlamalı veya rasyonel bilgi de idelerin bütün alanını kapsamaz. Duyusal bilgi ise sezgisel ve kanıtlamalı bilgiden daha da dardır (Locke, 1997: 479). Locke (1997: 497)'a göre, bilgimizin sınırlarının dar olmasının nedeni; birincisi idelerimizin eksikliği, ikincisi idelerimiz arasında görülebilir bağların eksikliği, üçüncüsü ise idelerimizi izleme ve incelemedeki eksikliktir.

İbn Haldun'un ileri sürdüğü "insanın nefsinde tanık olduğu" üç bilgi alanı ile Locke'un sınıflandırdığı duyusal bilgi, kanıtlamalı bilgi ve sezgisel bilginin örtüşmekle beraber, benzer ve bazı farklı yönlerinin de olduğu görülmektedir. Örneğin İbn Haldun'un bilgi anlayışındaki fizikî alanın bilgisi ile Locke'un epistemolojisindeki duyusal bilgi aynı bilgi türüdür, çünkü her ikisine de dış duyular aracılığı ile ulaşılır. İbn Haldun'un duyuüstü idrak veya ruhlar ve melekler alanının bilgisi ile Locke'un kanıtlamalı bilgi dediği bilgi türünün ise bazı yönlerden benzediği söylenebilir. Şöyle ki, İbn Haldun duyuüstü alanın bilgisinin insanın varlığını içinde gözlemlemesi ve eserlerden çıkarsama yapması ile bilinebileceğini söylerken Locke da kanıtlamalı veya rasyonel bilgiye ulaşırken aracı ideye ihtiyaç duyulduğunu ve uzun çıkarımlar ve kanıtlar gerektiğini ileri sürer. Locke'daki kanıtlamalı bilgi Tanriya ait bilgidir, dolayısıyla hem İbn Haldun hem de Locke'daki eserlerden çıkarsama yapılarak bilgisine ulaşılan bu alan metafizik alandır. 
İbn Haldun ayrıca bu alanın bilgisine aracısız olarak veya dış duyuların devreden çıktığı bazı durumlarda da ulaşılabileceğini ileri sürer.

Yukarıdaki benzerliklerin yanı sıra İbn Haldun ve Locke'da aracısız edinilen bilginin alanı ve edinilmesi konusunda bazı farklılıkların olduğu görülmektedir. Öncelikle İbn Haldun'da aracısız olarak bilgisine ulaşılabilen alan metafizik alan iken Locke da ise bu kendi varlığımız ile ilgili alandır. İkincisi, aracısız edinilen bu bilgiye İbn Haldun'a göre duyulardan kurtulan nefsin ruhanî âleme birleşmesi ve bazı ilmî ve gaybî idrakler kazanması ile ulaşılırken; Locke da ise zihnin ideler arasındaki bağlantıyı aracısız, yani dolaysız algılaması ile ulaşı1ır ve Locke bu bilgi türüne sezgisel bilgi der.

\section{E. Bilginin Değeri}

İbn Haldun, bilginin değeri konusunda duyu verilerinin soyutlanması ile elde edilen somut varlıklarla ilgili algıların, üst seviyelerde üretilen çok daha genel ve soyut kavramlara göre daha çok güvenilir ve hatadan uzak olduğunu ileri sürer. Çünkü "zihin çoğu defa ikinci derecede, soyutlanan genel kavramları değil de, somut varlıklara uygun olan birinci derecede soyutlanan tümelleri algıladığından zihnen verilen hüküm, gözle görülür ve duyularla algilanan şeyler derecesinde kesin olur. Duyu verilerinin soyutlanması ile elde edilen genel kavramlar dış dünyadaki varlıklar ile daha fazla uygunluk halindedir." (İbn Haldun, t. y: 516) Bunlar temel alınarak daha üst düzeylerde soyutlanan genel kavramlarda ise obje ile süje arasındaki aracılar birden fazladır. Birincilerin oluşturulmasında etkin olan zihinsel güç özel olarak "hayal gücü" yetisi iken, ikincilerin oluşturulmasındaki güç ise akıldır. Çünkü varlığın ilk algılanması sonucunda ulaşılan genel kavramı başka kavramlarla karşılaştırarak soyutlama işlemini yapıp, gitgide daha genel kavramlara, sonunda kendilerinden daha öteye bir soyutlamanın mümkün olmadığı en genel kavrama, töz kavramına ulaşan aklın kendisidir (Arslan, 1997: 371-372).

İbn Haldun'un yukarıdaki görüşlerinden dış duyular aracıllı̆ı ile ulaşılan fizikî alanın bilgisinin daha güvenilir olduğu sonucu çıkmaktadır, çünkü somut varlıklardan bilgi üretirken zihnin obje ile gerçekleştirdiği bağlantı dış dünyaya daha uygundur.

Aslında İbn Haldun ruhanî alanın bilgisini doğrudan ulaşılan ve daha güvenilir bilgi olarak kabul etmektedir. Ona göre, ruhun kendisine has olan idraki daha güvenilirdir, ancak bu sınırlıdır, çünkü ruh idrak konusu şeylerin sadece bir bölümünü idrak edebilir ki, bunlar da insan ilminin kuşattığ1 varlıklardan ibarettir. Yoksa onun idraki tüm var olanları kapsayacak kadar genel değildir (İbn Haldun, t. y: 518). Yani insan ruhanî alanın tamamının bilgisine ulaşamaz, bunun gerekçesini de İbn Haldun "ilâhî emirler insan 
idrâkinin üstündedir ve onun akıl ve düşünme dairesinden daha geniş olan bir dairedendir, aklın ve düşüncenin bir sınırı vardır, orada durup kendine ait olan alanın ötesine geçemez" şeklinde açıklar (İbn Haldun, t. y: 460).

İbn Haldun'a göre, aracısız olarak edinilen ruhanî alanın bilgisinin duyular aracılığı ile edinilen maddî alanın bilgisinden daha yüce ve daha güvenilir olmasının bir başka gerekçesi de ruhun idraklerinin zaman içinde unutulmamasidır (İbn Haldun, 2004: C. II, 849, 868).

J. Locke herhangi bir aracı idenin bulunmadığı sezgisel bilgiyi en açık ve en güvenilir bilgi olarak kabul etmektedir (Locke 1997). Ona göre, en kesin ve en güvenilir bilgi, objesine uygun tek bilgi olan kendi varlığımız hakkındaki bilgimizdir. Çünkü kendi var oluşumuzun bilgisini zihin hiçbir aracı ide kullanmadan, dolaysız olarak, doğrudan öylesine açık ve kesin olarak algilar ki bunun kanitlanmasına gerek kalmaz (Locke, 1997: 546547), bir başka deyişle, kendi var oluşumuzla ilgili bilgiyi sezgiyle elde ederiz. Kendi varlığımız ile ilgili bilginin en kesin ve en güvenilir bilgi olmasının nedeni, bu bilgiye zihinde gerçekleşen 'düşünme' işleminin kavranması sonucu ulaşılmasıdır. Bu kavrayışta zihin kendi üzerine katlanır ve suje ile obje adeta bir ve tek varlık olur. Locke bu noktada Descartes felsefesinin "kesin bilgiyi ancak kendimizi bilmede bulabileceğimiz" görüşüne yaklaşır. Ancak Descartes kendi bilincimizi kesin olarak bilişimize soyut bir akıl yürütme ile varırken Locke ise bu sonuca empirik bir yolla ve psikolojik çözümlemeyle varır (Gökberk, 1980: 338).

Locke'un bilgi anlayışında güvenilirlik bakımından ikinci sırayı kanıtlı bilgi alır. Ona göre, zihnin ideler arasındaki bağıntıyı aracı ideler ile algılayarak ulaştığı kanıtlı bilgi kesin olmakla birlikte sezgisel bilgi kadar açık değildir. Çünkü kanıtlı bilgiye ulaşırken aracı ideye ihtiyaç duyulduğundan ve uzun çıkarımlar ve kanıtlar gerektiğinde hafizanın zaman zaman hata yapma ihtimali olduğundan kanttl bilginin öncesinde bir bilgisizlik ve kuşku vardır (Locke, 1996: 304-306). Kesinlik ve güvenilirlik bakımından kendi varlığımızın bilgisini Tanrı'nın varlığı konusundaki bilgi takip eder. Bu kanıtlamalı bir bilgi olduğundan sezgisel bilgi kadar olmasa da kanıtlı bilginin kesinliğine sahiptir. Tanrı kendisiyle ilgili ideleri doğuştan zihnimize yerleştirmemiş olsa da, bize zihinlerimizi donatan yetileri vererek kendini tanıksız bırakmamıştır (Locke, 1997: 547-548). Akı1 duyularla algılanan bu dünyanın iç örgüsünü daha dikkatlice düşünüp, varlıklardaki güzellik, düzen, tertip ve hareketi gözledikten sonra, bu mükemmel eserin kaynağını, yapıcısını araştırmaya başlar (Locke, 1999: 45). Ve insan kendisinde ve kendi yapısında şaşmaz bir biçimde bulduğu şeyleri inceleyerek Tanrının varlığının bilgisine ulaşabilir (Locke, 1997: 549). Çünkü böylesine mükemmel bir eserin tesadüfen ve nedensiz olarak 
kendiliğinden meydana gelemeyeceği veya evrendeki cansız varlıkların ve kaba hayvanların kendilerinden çok daha mükemmel olan insanı yaratamayacağı tartışma götürmeyecek kadar açıktır (Locke, 1999: 45).

Güvenilirlik açısından üçüncü sırada duyusal bilgi bulunur. Locke'a göre, duyularımız aracılı̆̆ı ile dışımızda var olan şeyler üzerinde elde ettiğimiz bilgi sezgisel bilgimiz ya da zihnimizin açık ve soyut ideleri üzerinde usumuzu kullanarak yaptığımız çıkarımlar gibi tümüyle kesin bilgiler olmasa da yine de bilgi adını almayı hak etmiştir (Locke, 1996). Duyusal bilginin güvenilirlik bakımından en sonda yer almasının nedeni, alg1 yanılsaması olabileceğinden ve bireyler aynı objeyi donanımlarına ve alg1 seçiciliklerine göre farklı şekillerde algılayabileceğinden duyusal bilgideki algının gerçeği tam olarak yansıtmama olasılığının bulunmasıdır. Bir başka neden ise, objeler arasındaki bağlantıları birey kendisi düşündüğünden herkesin farklı bağlantılar kurarak farklı bilgiler edinme olasılığının bulunmasıdır (Locke, 1997: 558).

Görüldüğü gibi Locke, zihnin iki ide arasındaki uyuşma ya da uyuşmamayı, hiçbir aracı ide kullanmadan algılamasıyla ulaştı̆̆ sezgisel bilgiyi en güvenilir bilgi kabul etmektedir. İbn Haldun'da ise doğrudan ulaşılan ve daha güvenilir olan bilgi ruhanî alanın bilgisidir.

Sezgisel, kanıtlamalı ve duyusal bilginin sınırlı olduğunu göstermeye çalışan Locke, ruhlar üzerindeki bilgimizin ise daha da dar olduğunu ileri sürer, çünkü bu konuda, kendi içimizde, ruhumuzun işlemlerinin gözlem alanımıza girdikleri ölçüde onlar üzerinde düşünerek elde ettiklerimizin dışında hiçbir idemiz yoktur (Locke, 1997: 486-487). Ancak o, dış duyularla ulaşılamayan birçok durumlarda inanç ve olasılıkla yetinilmesi gerektiğini söyler, fizik ötesi ve ruh konusunda yetilerimiz kanıtlamalı bilgiye erişmeye yetemiyorsa bu tuhaf karşılanmamalıdır. Çünkü ahlâk ve dinin bütün yüksek amaçları, ruhun fizik ötesi felsefî kanıtlaması olmadan da yeterince sağlam temellere oturur (Locke, 1997: 481). Birçok durumlarda bir şeyin doğasını anlayamadığımız için onun varlığını inkâr etmek nasıl sağduyuya aykırı ise, bizde de düşünen bir şeyin olduğunu inkâr etmek sağduyuya aykırıdır. Bizdeki düşünen yönümüz üzerindeki kuşkumuz bile onun var oluşuna inancımızın bir kanıtıdır (Locke, 1996: 311-312).

Bir şeyin doğasının anlaşılamamasının onun inkârı anlamına gelmediğini savunan Locke gibi İbn Haldun da dış dünyadaki algılanamayan varlıkların yok sayılamayacağını ileri sürer. Bilgi ile bilginin konusu olan varlık, duyum ile duyumun konusu olan duyusal şey arasında bir ayrım yapan ve birincilerin varlığının ancak ikincilere bağlı olduğunu, çünkü ikincilerin her bakımdan birincilerden önce geldiğini ileri süren Aristoteles 
gibi, İbn Haldun da algılanan obje ile algılama arasını ayırır ve dış dünyadaki algılanmayan varlıkların yok sayılamayacağını belirtir. Ve "biz algilamasak da kendisinden ayrıldığımız bir memleket ile varmak istediğimiz, henüz gözlerimiz önünde bulunmayan memleketin varlığını kesin olarak bildiğimizi, bulutların üstünde kalan göğün ve yıldızların varlığının da bu şekilde bilindiğini” (İbn Haldun, 2004: C. II, 858) söyler.

\section{SONUÇ ve DEĞERLENDİRME}

Felsefe tarihinin iki önemli düşünürü olan İbn Haldun ve J. Locke’un epistemoloji ile ilgili bazı görüşlerinin karşılaştırıldığı bu çalışmanın sonunda özetle şunları söylemek mümkündür:

Öncelikle her iki düşünür de doğuştan birtakım bilgiler getirildiğini kabul etmezler. İbn Haldun özel olarak bu konu ile ilgilenmediğinden onun doğuştan getirilen bilgiler ile ilgili geniş ve ayrıntılı görüşlerine rastlanmaz. Fakat Locke bu konuyu geniş olarak incelemiş ve doğuştan getirilen herhangi bir bilginin yanı sıra teorik ve pratik ilkelerin de olmadığını ayrıntılı bir şekilde anlatarak kanıtlamaya çalışmıştır.

Doğuştan getirilen bilgiler konusunda olduğu gibi bilginin kaynağ 1 konusunda da benzer düşünceleri paylaşan İbn Haldun için duyular bilgi kaynağı, Locke için de bilginin iki kaynağından biridir ve Locke'ta bilginin ikinci kaynağ 1 düşünümdür. Locke'un epistemolojisinde duyum ve düşünüm İbn Haldun'daki dış duyular ve iç duyuların karşılığı olarak kullanılmaktadır. Gerek İbn Haldun'un iç duyular gerekse Locke'un düşünüm sürecinin her ikisinde de duyu verileri benzer işlemlerden geçirilerek bilgiye ulaşıllır.

Her ne kadar iki düşünür de bilginin zihinde duyu verileri üzerinde fikir veya düşünmeyi sağlayan iç duyular veya düşünüm tarafindan gerçekleştirilen bazı işlemler sonucunda oluşturulduğunu kabul etse de zihinde doğuştan gelen ve duyu verilerini bilgiye dönüştüren genel fikir veya kategorilerden bahsetmezler.

Doğuştan getirilen birtakım fikirlerin, başka bir ifade ile Platon'un epistemolojisindeki ideaların veya ortaçağda epistemolojinin hararetle tartışılan konularından biri olan, zihnin ikinci dereceden soyutlamasının ürünü olarak kabul edilen, tümellerin varlığını kabul etmeyen İbn Haldun dış dünyadaki nesnelerin varlığını kabul eder. Bu şu anlama gelmektedir: İbn Haldun'a göre, iki çeşit tümel vardır, birincisi her türlü soyutlamalar olmayıp dış dünyada varlığı ve gerçek içeriği olan tümellerdir; bunlar doğuştan değil, düşüncenin ürünleridirler ve zihin bunları oluşturur. İkincisi ise zihnin ikinci dereceden soyutlamasının ürünü olan tümellerdir. Birinci 
tümellerin oluşturulmasındaki etkin güç hayal gücü iken, ikincilerin oluşturulmasındaki etkin olan güç ise akıldır. İbn Haldun'a göre, bilginin konusu tümellerdir, fakat burada söz konusu olan tümeller her türlü soyutlamalar değil, varlıkta karşılığı ve gerçek içeriği olan tümellerdir (Arslan, 1997: 377).

İbn Haldun, gerçekten inanılır, güvenilir bilgilere sahip olmak isteyen herhangi bir felsefi-ilmi disiplinin bu birinci dereceden soyutlamalar olan genel kavramlar üzerinde çalışması ve onları aşmaması gerektiğini belirtir, bilginin konusu bu birinci dereceden soyutlamalar olmalıdır. İkinci dereceden soyutlamalara gelince onların dış dünyada herhangi bir gerçeklikleri yoktur. Tümeller konusunda J. Locke da aşırı adçı bir tutum sergiler (Russell, 1970: 225) ve var olan şeylerin hepsinin tikeller olduğunu ileri sürer. Var olan şeyler tikeller olduğuna göre genel kavramlar nasıl edinilir? Ona göre, her tikel şeyin bir adının olması olanaksız olduğundan "insan" gibi pek çok bireylere uygulanabilecek genel düşüncelerin sınırı çizilerek onlara adlar verilir (Locke, 1996: 245). Onların genelliği sadece değişik tek tek şeylere uygulanabilir olmasındandır, aslında zihinlerimizdeki genel düşünceler, kendi içlerinde, var olan başka her şey gibi tikeldir (Russell, 1970: 225). Bilginin tikel şeyler üzerine kurulduğunu ancak şeyleri genel adlar altında türlere indirgeyen genel görüşlerle genişlediğini düşünen Locke'a göre bilginin konusunu ideler oluşturur.

Bilginin konusunun tikeller veya birinci dereceden soyutlamalar olan tümellerin olması gerektiğini düşünen İbn Haldun ve Locke, aynı zamanda dış dünyadaki her varlığın algılanamadığını ve bundan dolayı da bilgimizin sınırlı olduğunu göstermeye çalışır, fakat dış duyuların ulaşamadığı varlıkların yok sayılamayacağını da vurgularlar.

Görüldüğü gibi yaşadığ 1 dönemler arasında üç asır gibi bir fark olan ve farklı kültür çevrelerinde yaşamış İbn Haldun ile J. Locke'un epistemoloji ile ilgili görüşleri arasında çok sayıda benzerlikler bulunmaktadır.

Her iki düşünürün de doğuştan getirilen fikirler ve bilginin iki kaynağından birinin dış duyular olduğunu kabul etmeleri açısından empirist bir yaklaşıma sahip olduğu görülür ve gerek İbn Haldun'un gerekse Locke'un daha çok realist birer deneyci olarak objenin zihne yansıdığ 1 ve orada dış nesneye uygun olarak bilgisinin oluştuğunu kabul ettikleri söylenebilir. Zaten J. Locke da empirizmin fikir babası olarak kabul edilmektedir. Ancak burada bilginin oluşum süreci dikkatle incelendiğinde bu iki düşünürün bu sürecin birinci aşamasında empirist ikinci aşamasında ise rasyonalist bir yaklaşıma sahip olduklarını söylemek de mümkündür. Fakat burada kastedilen rasyonalizm bilginin aklın ürünü olduğunu savunan 
görüş değil, Aristoteles'in rasyonalizmidir. Platon'un doğuştancı akılc1lığına karşı çıkan Aristoteles'in rasyonalizmine göre, akılda bilgi yoktur, bilgiler duyularımızla deneylerden elde ettiğimiz duyu verilerinden aklımız tarafından yapılır. Algıların zihinde düzenlenmesi sonucu hatıralar oluşur, benzer hatıralardan oluşan bir kitleye sahip olunduğunda deneyim denen şeye sahip olunur ve özel olgulardan oluşan bir çoğunluk olan deneyim sanki tek bir genel olgu halinde sıkıştırılırsa bilgi meydana gelir. Bir başka deyişle bilgi duyu algısının genelleştirilmesi sonucu oluşur (Barnes, 2002: 88-90). Bütün bu zihinde gerçekleşen işlemleri gerçekleştiren güç de akıl olduğuna göre, bilgiyi yapan ve meydana getiren akıldır (Arslan, 2007: 224).

İbn Haldun ve Locke'un bilginin oluşum sürecinin ikinci aşamasında rasyonalist bir yaklaşıma sahip oldukları tezi şu şekilde açıklanabilir: İbn Haldun'a göre bilginin ikinci kaynağı iç duyular, Locke'a göre de düşünümdür. İbn Haldun'un epistemolojisindeki nefsin görünmeyen organları olan ve onlar aracıllı̆ı ile görünmeyenlerin idrak edildiği iç duyular duyularla ulaşılan duyu verilerini bir bütün halinde algılayan güç (müşterek his), duyu verilerini dışarıdaki maddelerinden ayırıp soyutlayarak şekil veren ve zihne imajlarını yerleştiren hayal gücü (muhayyile), somut ve bireysel şeylerle ilgili anlamları idrak eden güç (vâhime), bellek (hafiza) ve fikir (nefs-i nâtıka) dir (İbn Haldun, t. y: 97, 104).

"Fikir" İbn Haldun'un bilgi anlayışının anahtar kavramlarından biridir ve o fikri akıl sözü yerine de kullanır. İnsana ayrıcalıklı olarak verilen (Ibn Haldun, t. y: 42) ve onu diğer canlılardan üstün kılan bir güç (İbn Haldun, 2004: C. II, 766) olan fikir idrak etmenin ve gerçeği kavramanın doğal bir aracidır (İbn Haldun, t. y: 490, 536). İdrâk olunan şeyler birbirinden kopuk ve birbirine bağlı değildir, bunların birbirine bağlanması sadece fikirle olur. Fikir, algılananlar arasında sebep-sonuç ilişkisi kurarak duyularla algılanan nesnelerin imajlarını çıkartır, bunları bir takım zihinsel işlemlerden geçirerek bunlardan bir takım imajlar daha soyutlar (İbn Haldun 2004, C. II, 766, 768). Fikir, somut varlıklara bakıp, varlığı olduğu gibi kavramak istediği zaman, bu kavramanın doğru ve gerçeğe uygun olarak gerçekleşmesi için kesin bilgi ifade eden aklî delile dayanarak, zihnin bu somut kavramlarının bazısını diğerine katması ve kıyaslaması, diğer bazılarını da birbirinden uzaklaştırması gerekir (İbn Haldun, t. y: 514). "O halde fikir, duyuların ötesindeki söz konusu suretler üzerinde analiz ve sentez yolu ile zihnin faaliyette bulunmasıdır" (İbn Haldun, 2004: C. II, 766). Yani duyuların görevi zihne algı girdisini sağlamak, fikrin görevi de bu girdileri işlemektir. Fikrin duyu verileri üzerinde işlemler yaptığı yer ise zihindir.

Locke'ta da idelerin, dolayısıyla bilginin ikinci kaynağı düşünümdür. Algılama, hafiza, ayırdetme, birleştirme, genişletme ve soyutlama gibi 
zihinsel işlemlerden oluşan düşünüm sürecinde duyu nesnelerinin çoğunun özel ideleri zihne girerler ve zihin bunlar üzerinde adı geçen işlemleri gerçekleştirir ve bu idelerin ötesine geçemez. Bir başka ifade ile ilk ideler zihne ulaşır ulaşmaz zihnin bu yetileri kendiliğinden çalışmaya başlar ve bundan çıkan sonuca göre, daha önce duyuda bulunmayan hiçbir şey zihinde yer alamaz. Ve bu iki yetinin işbirliği içerisinde çalışmasıyla bilgi üretilir.

Özetle, hem İbn Haldun hem de Locke göre bilginin oluşum sürecindeki etkin olan güç söz konusu zihinsel işlemleri gerçekleştiren "fikir" veya "akıl"dır. Farklı bir şekilde söylenecek olursa bilginin ikinci kaynağı akıldır. Akıl olmadan duyu verileri işlenemeyecek ve bilgi de üretilemeyecektir. Sonuç olarak sanki bu iki düşünürün bilgi anlayışında deneycilik ile akılcılık uzlaşmaktadır. Çünkü İbn Haldun'un epistemolojisinde süje ile obje arasındaki ilk bağlantı noktasını oluşturan duyuların, idrak ettiği şeyler birbirinden kopuk olduğundan, algılananların birbirine bağlanması fikirle olur ve bilgiye de duyu verilerinin zihinsel işlemlerden geçmesi sonucunda ulaş1ır. J. Locke'ta da akıl olmadan duyular harekete geçirilse bile en fazla hayvanların düzeyine ulaşılabilir.

Ancak şunun vurgulanmasında yarar vardır: Locke'ta düşünüm duyu verileri ile sınırlı olup onları aşamazken ve bilginin ikinci kaynă̆ını oluştururken, idealizmde ise bilginin kaynağ doğuştan getirilen idelerdir ve düşünüm bu idelerin kavranması ve hatırlanması için ancak kullanılan bir yöntemdir, bir başka ifade ile düşünüm Locke epistemolojisinde kaynak, idealizmde ise süreçle ilgilidir. Sonuç olarak, Locke'un düşünümü bilginin kaynaklarından biri olarak kabul etmesi onun idealizme kaydığını göstermez, çünkü süreçle bilginin kaynağının ayrılması gerekir.

İki düşünürün epistemolojilerinde eğitim felsefesine temel oluşturabilecek olan kavram ve konular ise şöyle sıralanabilir:

Zihnin doğduğunda boş bir levha gibi olması, fikir kavramı, doğrunun yanlıştan ayırt edilmeye başlandığı dönem olan öğrenim yaşı (temyiz), doğruyu yanlıştan ayırt edebilen akıl, genel deneyimler edinebilen tecrübî akıl, soyut düşünebilen kuramsal akıl ve insanın varlığını gerçekleştirmesinin birden olmayıp yaşam boyu süren bir sürece yayılması konusu. Ayrıca bilginin kaynağı ve iç duyuların işleyişi, bir başka ifade ile bilginin oluşum süreci ile ilgili görüşler de önemli felsefî temellerdendir. Bunların yanı sıra bilginin konusunun neler olması gerektiği ve değeri ile ilgili görüşleri de eğitimde program veya içeriğe temel oluşturabilecek olan konular arasında gösterilebilir. 


\section{KAYNAKLAR}

Açıkgenç, A. (2009). "Küreselleşme Karşısında Yeni Bir Eğitim Felsefesine Doğru”, Uluslararası Eğitim Felsefesi Kongresi Küreselleşme Sürecinde Eğitim Sorunlarının Felsefi Boyutu, Ankara.

Adamson, P. Taylor, R. C. (2008). İslam Felsefesine Giriş, (Çev: C. Kaya). (2. Bask1). İstanbul: Küre Yayınları.

Adıvar, A. A. (1950). "İbn Haldun”, İslam Ansiklopedisi, Milli Eğitim Basımevi, C. 5, İstanbul.

Akyüz, Y. (2004). Türk Eğitim Tarihi M.Ö 1000-M.S. 2004, 9. Bask1, Ankara: Pegem A Yayıncılık.

Al-Azmeh, (1998). "İbn Khaldun", Encyclopedia of Arabic Literature, Volume I, London.

Arslan, A. (1997). Ibn-i Haldun, 2. Bask1, Ankara: Vadi Yayınları.

Arslan, A. (1999). İslam Felsefesi Üzerine, Ankara:Vadi Yayınları.

Arslan, A. (2007). İlkçă̆ Felsefe Tarihi Aristoteles, İstanbul: İstanbul Bilgi Üniversitesi Yayınları.

Aydın, H. (2007). Felsefî Temelleri Işı̆̆̆ında Yapılandırmacılık, Ankara: Nobel Yayın Dağıtım.

Barnes, J. (2002). Aristoteles Düşüncenin Ustaları, İstanbul: Altın Kitaplar Yayınevi.

Canatan, K. (2006). “İbn Haldun'un Eğitim Sosyolojisi”, Eski Yeni Sonbahar, Say1 3.

Diemer, A. (2001). "Bilgi Kuramı”, Günümüzde Felsefe Disiplinleri, Doğan Özlem'in Bütün Çevirileri-2, İstanbul: İnkılâp Kitabevi.

Enan, M. A. (1979). Ibn Khaldun His Life And Work, Kitab Bhavan New Delh1-110 002.

Erden, M., Akman, Y. (2006). (15. Bask1). Eğitim Psikolojisi GelişimÖğrenme-Öğretme, Ankara: Arkadaş Yayınevi.

Ev, H. (2007). “İbn Haldun'un Eğitim Görüşü”, Yayımlanmamış Doktora Tezi, İzmir.

Gutek, G. (2001). Eğitime Felsefî ve İdeolojik Yaklaşımlar”. (Çev: N. Kale). Ankara: Ütopya Yayınevi. 
Güneş, F. (2010). "Eğitime Yapılandırıcı Yaklaşımla Gelen Yenilikler", Ĕgitime Bakış Eğitim-Öğretim Ve Bilim Araştırma Dergisi, Say1 16.

Heınemann, F. (2001). "Bilgi Kuramı", Günümüzde Felsefe Disiplinleri, Doğan Özlem'in Bütün Çevirileri-2, İstanbul: İnkılâp Kitabevi.

Helvacıŏlu, E. (1999). İbn Haldun Özel Sayısı, Bilim ve Ütopya.

İbn Haldun, (tarih yok). Mukaddime, el-Mektebetü't-Tiyariyyetü'l-Kübra Yayınları, Mustafa Muhammet Matbaası, Misır.

İbn Haldun (1989). Mukaddim.(Çev: Z. K. Ugan). İstanbul: Milli Eğitim Basımevi.

İbn Haldun (2004). Mukaddime. (Çev: S. Uludağ). İstanbul: Dergâh Yayınlar1.

İbn Haldun, (2004). Bilim Ile Siyaset Arasında Hatıralar. (Türkçesi: V. Akyüz). İstanbul: Dergâh Yayınları.

İbn Haldun, (1977). Şifâu's-Sâil li-Tehzibi'l-Mesail, Hazırlayan, Süleyman Uludağ. İstanbul: Dergah Yayınları.

Locke, J. (1997). An Essay Concerning Human Understanding, London: Penguin Classics.

Locke, J. (1996). Insan Anlı̆̆ Üzerine Bir Deneme. (Çev: V. Hacıkadiroğlu). İstanbul: Kabalcı Yayınevi.

Locke, J. (1999). Tabiat Kanunu Üzerine Denemeler. (Çev: İ. Çetin). İstanbul: Paradigma.

Locke, J. (2004). Eğitim Üzerine Düşünceler, (Çev: H. Zengin). İstanbul: Morpa Kültür Yayınları.

Okumuşlar, M. (2008). Yapılandırmacı Yaklaşım Ve Din Eğitimi, Konya: Yediveren Kitap.

Piaget, J. (2004). Çocuğun Zihinsel Gelişimi. (Çev: H. Portakal). (2. Basım). İstanbul: Cem Yayınevi.

Rosenthal, F. (1987). "Ibn Khaldun”, Encyclopedia of Religion, C. VI, New York.

Russell, B. (1970). Batı Felsefe Tarihi Yeni Çağ, Üçüncü ve Son Cilt. (Çev: M. Sencer). İstanbul: Kitaş Yayınları.

Tokatl1, A. (1973). Ansiklopedik Felsefe Sözlü̆̆̈̈, Ankara: Bilgi Yayınevi.

Türker, S. (2002). Aristoteles Gazzali İle Leibniz'de Yargı Mantığı, İstanbul: Dergah Yayınları. 